Supporting Information

\title{
Ultrathin Pt-Cu-Ni Ternary Alloy Nanowires with Multimetallic Interplay for Boosted Methanol Oxidation Activity
}

Zhixue Zhang, ${ }^{\dagger \# ~ M i a o ~ X i e, ~}{ }^{, \#}$ Zhaojun Liu, ${ }^{\dagger}$ Yiming Lu, ${ }^{,}$Shumeng Zhang, ${ }^{\dagger}$ Moxuan Liu, ${ }^{\dagger}$ Kai Liu, ${ }^{\dagger}$ Tao Cheng, ${ }^{* *}$ and Chuanbo Gao ${ }^{* *}$

${ }^{\dagger}$ Center for Materials Chemistry, Frontier Institute of Science and Technology, and State Key Laboratory of Multiphase Flow in Power Engineering, Xi'an Jiaotong University, Xi' an, Shaanxi 710054, China.

Institute of Functional Nano \& Soft Materials (FUNSOM), Jiangsu Key Laboratory for CarbonBased Functional Materials \& Devices, Joint International Research Laboratory of Carbon-Based Functional Materials and Devices, Soochow University, Suzhou, Jiangsu 215123, China.

*Email: gaochuanbo@mail.xjtu.edu.cn (C.G.) tcheng@ssuda.edu.cn (T.C.)

${ }^{\#}$ Z.Z. and M.X. contributed equally to this work. 


\section{Full Experimental Details.}

Materials. Chloroplatinic acid hexahydrate $\left(\mathrm{H}_{2} \mathrm{PtCl}_{6} \cdot 6 \mathrm{H}_{2} \mathrm{O}\right)$, cupric chloride $\left(\mathrm{CuCl}_{2}\right)$, nickel chloride hexahydrate $\left(\mathrm{NiCl}_{2} \cdot 6 \mathrm{H}_{2} \mathrm{O}\right)$, polyvinylpyrrolidone ( $\left.\mathrm{PVP}, \mathrm{Mw} 40000\right)$, sodium sulfite $\left(\mathrm{Na}_{2} \mathrm{SO}_{3}\right)$, ethylene glycol (EG), diethylene glycol (DEG), and formic acid (HCOOH, 98\%) were purchased from Sigma-Aldrich and used without purification.

Synthesis of ultrathin Pt-Cu-Ni ternary alloy nanowires. In a typical synthesis of $\mathrm{Pt}_{1} \mathrm{Cu}_{0.84} \mathrm{Ni}_{0.11}$ alloy nanowires, $100 \mu \mathrm{L}$ of $\mathrm{H}_{2} \mathrm{PtCl}_{6}(0.1 \mathrm{M}), 100 \mu \mathrm{L}$ of $\mathrm{CuCl}_{2}(0.1 \mathrm{M}), 100 \mu \mathrm{L}$ of $\mathrm{NiCl}_{2}(0.1 \mathrm{M}), 1 \mathrm{~mL}$ of PVP $(5 \mathrm{wt} \%), 400 \mu \mathrm{L}$ of $\mathrm{Na}_{2} \mathrm{SO}_{3}(0.1 \mathrm{M})$, and $500 \mu \mathrm{L}$ of $\mathrm{HCOOH}$ were dissolved in $8.3 \mathrm{~mL}$ EG in a $15 \mathrm{~mL}$ Teflon-lined stainless autoclave and heated at $205^{\circ} \mathrm{C}$ for $6 \mathrm{~h}$. The solid product was collected by centrifugation and washed with $\mathrm{H}_{2} \mathrm{O}$. The compositions of the $\mathrm{Pt}-\mathrm{Cu}-\mathrm{Ni}$ ternary alloy nanowires were tuned by adjusting the amounts of the metal precursors (Table S1).

Table S1. Synthesis of ultrathin Pt-Cu-Ni ternary alloy nanowires of different compositions.

\begin{tabular}{cccc}
\hline Entry & $\mathrm{H}_{2} \mathrm{PtCl}_{6}(0.1 \mathrm{M}) / \mu \mathrm{L}$ & $\mathrm{CuCl}_{2}(0.1 \mathrm{M}) / \mu \mathrm{L}$ & $\mathrm{NiCl}_{2}(0.1 \mathrm{M}) / \mu \mathrm{L}$ \\
\hline $\mathrm{Pt}_{1} \mathrm{Cu}_{0.84} \mathrm{Ni}_{0.11}$ & 100 & 100 & 100 \\
$\mathrm{Pt}_{1} \mathrm{Cu}_{0.53} \mathrm{Ni}_{0.75}$ & 100 & 50 & 150 \\
$\mathrm{Pt}_{1} \mathrm{Cu}_{0.61} \mathrm{Ni}_{0.38}$ & 100 & 75 & 125 \\
$\mathrm{Pt}_{1} \mathrm{Cu}_{2.05} \mathrm{Ni}_{0.04}$ & 100 & 150 & 50 \\
\hline
\end{tabular}

Synthesis of ultrathin Pt-Cu binary alloy nanowires. In a typical synthesis of $\mathrm{Pt}_{1} \mathrm{Cu}_{0.83}$ alloy nanowires, $150 \mu \mathrm{L}$ of $\mathrm{H}_{2} \mathrm{PtCl}_{6}(0.1 \mathrm{M}), 150 \mu \mathrm{L}$ of $\mathrm{CuCl}_{2}(0.1 \mathrm{M}), 1 \mathrm{~mL}$ of PVP $(5 \mathrm{wt} \%), 300 \mu \mathrm{L}$ of $\mathrm{Na}_{2} \mathrm{SO}_{3}(0.1 \mathrm{M})$, and $500 \mu \mathrm{L}$ of $\mathrm{HCOOH}$ were dissolved in $8.4 \mathrm{~mL}$ EG in a Teflon-lined stainless autoclave and heated at $180{ }^{\circ} \mathrm{C}$ for $6 \mathrm{~h}$. The solid was collected by centrifugation and washed with $\mathrm{H}_{2} \mathrm{O}$. The compositions of the Pt-Cu binary alloy nanowires were tuned by adjusting the amounts of the metal precursors (Table S2).

Table S2. Synthesis of ultrathin Pt-Cu binary alloy nanowires of different compositions.

\begin{tabular}{ccc}
\hline Entry & $\mathrm{H}_{2} \mathrm{PtCl}_{6}(0.1 \mathrm{M}) / \mu \mathrm{L}$ & $\mathrm{CuCl}_{2}(0.1 \mathrm{M}) / \mu \mathrm{L}$ \\
\hline $\mathrm{Pt}_{1} \mathrm{Cu}_{0.38}$ & 225 & 75 \\
$\mathrm{Pt}_{1} \mathrm{Cu}_{0.83}$ & 150 & 150 \\
$\mathrm{Pt}_{1} \mathrm{Cu}_{1.24}$ & 100 & 200 \\
$\mathrm{Pt}_{1} \mathrm{Cu}_{1.33}$ & 75 & 225 \\
\hline
\end{tabular}


Synthesis of ultrathin Pt-Ni binary alloy nanowires. In a typical synthesis of $\mathrm{Pt}_{1} \mathrm{Ni}_{0.28}$ alloy nanowires, $150 \mu \mathrm{L}$ of $\mathrm{H}_{2} \mathrm{PtCl}_{6}(0.1 \mathrm{M}), 150 \mu \mathrm{L}$ of $\mathrm{NiCl}_{2}(0.1 \mathrm{M}), 1 \mathrm{~mL}$ of PVP $(5 \mathrm{wt} \%), 300 \mu \mathrm{L}$ of $\mathrm{Na}_{2} \mathrm{SO}_{3}(0.1 \mathrm{M})$, and $500 \mu \mathrm{L}$ of $\mathrm{HCOOH}$ were dissolved in $8.4 \mathrm{~mL}$ EG in a Teflon-lined stainless autoclave and heated at $205{ }^{\circ} \mathrm{C}$ for $6 \mathrm{~h}$. The solid product was collected by centrifugation and washed with $\mathrm{H}_{2} \mathrm{O}$. The compositions of the Pt-Ni binary alloy nanowires were tuned by adjusting the amounts of the metal precursors (Table S3).

Table S3. Synthesis of ultrathin Pt-Ni binary alloy nanowires of different compositions.

\begin{tabular}{ccc}
\hline Entry & $\mathrm{H}_{2} \mathrm{PtCl}_{6}(0.1 \mathrm{M}) / \mu \mathrm{L}$ & $\mathrm{NiCl}_{2}(0.1 \mathrm{M}) / \mu \mathrm{L}$ \\
\hline $\mathrm{Pt}_{1} \mathrm{Ni}_{0.09}$ & 270 & 30 \\
$\mathrm{Pt}_{1} \mathrm{Ni}_{0.20}$ & 225 & 75 \\
$\mathrm{Pt}_{1} \mathrm{Ni}_{0.28}$ & 150 & 150 \\
$\mathrm{Pt}_{1} \mathrm{Ni}_{0.35}$ & 100 & 200 \\
\hline
\end{tabular}

Synthesis of ultrathin monometallic Pt nanowires. In a typical synthesis of Pt nanowires, $200 \mu \mathrm{L}$ of $\mathrm{H}_{2} \mathrm{PtCl}_{6}(0.1 \mathrm{M}), 1 \mathrm{~mL}$ of PVP $(5 \mathrm{wt} \%), 300 \mu \mathrm{L}$ of $\mathrm{Na}_{2} \mathrm{SO}_{3}(0.1 \mathrm{M})$, and $500 \mu \mathrm{L}$ of $\mathrm{HCOOH}$ were dissolved in $8.4 \mathrm{~mL}$ of EG in a Teflon-lined stainless autoclave and heated at $205^{\circ} \mathrm{C}$ for $6 \mathrm{~h}$. The solid product was collected by centrifugation and washed with $\mathrm{H}_{2} \mathrm{O}$.

Electrochemical measurements. Electrochemical measurements were conducted on a CHI760E electrochemical workstation (CH Instruments, Inc.) with a three-electrode system. A glassy carbon electrode $\left(0.196 \mathrm{~cm}^{2}\right)$, a Pt foil $\left(1 \times 1 \mathrm{~cm}^{2}\right)$, and a $\mathrm{Ag} / \mathrm{AgCl}(3 \mathrm{M})$ electrode were used as the working, counter, and reference electrodes, respectively. All potentials were converted into values with respect to a reversible hydrogen electrode (RHE). Commercial Pt/C (JM, $20 \mathrm{wt} \%$ $\mathrm{Pt} / \mathrm{XC72R}$, HiSPEC 3000) was used as a reference catalyst.

The nanowires were supported on carbon black (Vulcan XC-72) with a Pt loading of $\sim 15 \mathrm{wt} \%$. Then, all the catalyst were supported on carbon and activated by annealing in $\mathrm{H}_{2}(5 \mathrm{vol} \%)$ at $200{ }^{\circ} \mathrm{C}$ for $2 \mathrm{~h}$ to ensure the clean surface of the catalysts. An ink of the catalyst was prepared by ultrasonically mixing the catalyst with water, isopropanol, and $5 \mathrm{wt} \%$ Nafion (volume ratio, 1: 1 : 0.02 ) for $1 \mathrm{~h}$. Then, a certain volume of the ink (Pt: $2 \mu \mathrm{g}$ ) was dropped onto the working electrode and dried in the air. Cyclic voltammetry (CV) curves were recorded in $\mathrm{N}_{2}$-saturated $0.5 \mathrm{M} \mathrm{H}_{2} \mathrm{SO}_{4}$ in the potential range of $0.05-1.1 \mathrm{~V}$ at a sweep rate of $50 \mathrm{mV} \mathrm{s}^{-1}$. The electrochemically active surface area (ECSA) was calculated based on the charges associated with the adsorption of a monolayer of hydrogen on the Pt surface in the region of $0.05-0.4 \mathrm{~V}$ after the double-layer 
correction (reference value: $210 \mathrm{C} \mathrm{cm}^{-2}$ ). The electrocatalytic activities of the catalysts in the methanol oxidation reaction (MOR) were evaluated by the CV and chronoamperometry (CA) techniques. The MOR was performed in $\mathrm{N}_{2}$-saturated $1 \mathrm{M} \mathrm{CH}_{3} \mathrm{OH}+0.5 \mathrm{M} \mathrm{H}_{2} \mathrm{SO}_{4}$ at a scan rate of $50 \mathrm{mV} \mathrm{s}^{-1}$. CA curves were recorded at $0.8 \mathrm{~V}$ for $5,000 \mathrm{~s}$ and $20,000 \mathrm{~s}$ to investigate the catalytic durability of the electrocatalysts. CO stripping voltammograms were obtained by holding the working electrode at $0.1 \mathrm{~V}$ for $30 \mathrm{~min}$ in CO-saturated $0.5 \mathrm{M} \mathrm{H}_{2} \mathrm{SO}_{4}$ followed by $\mathrm{N}_{2}$ purging for $30 \mathrm{~min}$ to remove the excess $\mathrm{CO}$ and a potential scan from 0.05 to $1.1 \mathrm{~V}\left(20 \mathrm{mV} \mathrm{s}^{-1}\right)$.

Characterizations. Transmission electron microscopy (TEM) was performed on a Hitachi HT7700 microscope operated at $100 \mathrm{kV}$. High-resolution TEM (HRTEM) images and elemental dispersive X-ray spectroscopy (EDS) elemental mappings were acquired using a JEOL JEM-F200 microscope operated at $200 \mathrm{kV}$. X-ray diffraction (XRD) patterns were recorded on a Rigaku SmartLab Powder X-ray diffractometer equipped with $\mathrm{Cu} K \alpha$ radiation and a D/TEX Ultra detector. Inductively coupled plasma mass spectrometry (ICP-MS) was performed on a NexION 350D. Xray photoelectron spectroscopy (XPS) data were collected on a Thermo Fisher ESCALAB Xi+ spectrometer equipped with monochromatic $\mathrm{Al} \mathrm{K} \alpha$ radiation.

DFT calculation details. The quantum mechanics $(\mathrm{QM})$ calculations were carried out using the VASP software, version 5.4.4. ${ }^{1-3}$ We used the Perdew, Burke and Ernzerhof (PBE) ${ }^{4}$ flavor of density functional theory (DFT) with the post-stage DFT-D3 method to correct for London dispersion (van der Waals attraction) with Becke-Johnson damping. ${ }^{5}$ The projector augmented wave (PAW) method was used to account for core-valence interactions. ${ }^{6-7}$ The kinetic energy cutoff for plane wave expansions was set to $400 \mathrm{eV}$, and reciprocal space was sampled by the $\Gamma$-centered Monkhorst-Pack scheme using a $3 \times 3 \times 1 \mathrm{~K}$-point grid for all systems. The vacuum layer is at least $20 \AA$ above the surface. The convergence criteria are $1 \times 10^{-5} \mathrm{eV}$ energy differences for solving the electronic wave function. All geometries (atomic coordinates) were converged to within $3 \times$ $10^{-2} \mathrm{eV} \AA^{-1}$ for maximal components of forces.

In our calculation, 4 simulation models were considered, including pure $\mathrm{Pt}$, $\mathrm{Pt}-\mathrm{Cu}, \mathrm{Pt}-\mathrm{Ni}$, and Pt-Cu-Ni alloys, respectively. The pure Pt model was obtained by appropriately cutting from the unit cell and exposing the (101) surface, which was simulated by $3 \times 3$ unit cells (36 atoms) with 4 periodic atom layers. We also used the homogeneous $\mathrm{Pt}_{9} \mathrm{Cu}_{8} \mathrm{Ni}_{1}, \mathrm{Pt}_{5} \mathrm{Cu}_{4}$ and $\mathrm{Pt}_{4} \mathrm{Ni}_{1}$ alloys as the models for the catalysts of $\mathrm{Pt}_{1} \mathrm{Cu}_{0.84} \mathrm{Ni}_{0.11}, \mathrm{Pt}_{1} \mathrm{Cu}_{0.83}$, and $\mathrm{Pt}_{1} \mathrm{Ni}_{0.28}$, respectively. During the 
geometry optimization, the atoms in the 2 bottom layers were fixed at their bulk positions, whereas the rest atoms were allowed to be fully relaxed at their bulk-truncated structure.

In this work, all free energies at $298.15 \mathrm{~K}$ were calculated as

$$
G=E_{\text {elec }}+E_{Z P E}-T \times S_{m}^{v}
$$

where $E_{\text {elec }}$ is the electronic energy of the surface with adsorbed $\mathrm{OH} / \mathrm{CO}$ molecule. The vibrational frequencies were evaluated for only surface adsorbates and were calculated. According to the calculated frequency results, we obtain the zero-point energy $\left(E_{Z P E}\right)$ and adsorption entropy $S_{m}{ }^{v}$.

$$
S_{m}^{v}=\sum_{\tilde{v}}^{\tilde{v} i} R\left\{\frac{\beta h c \tilde{v}}{e^{\beta h \tilde{v}}-1}-\ln \left(1-e^{-\beta h \tilde{v}}\right)\right\}
$$

where $R$ is the gas constant, $\beta$ is $1 / T \times k_{\mathrm{b}}$ ( $k_{\mathrm{b}}$ : Boltzmann constant), $h$ is the Plank constant, $c$ is the light speed, and $v$ is the wavenumber. 


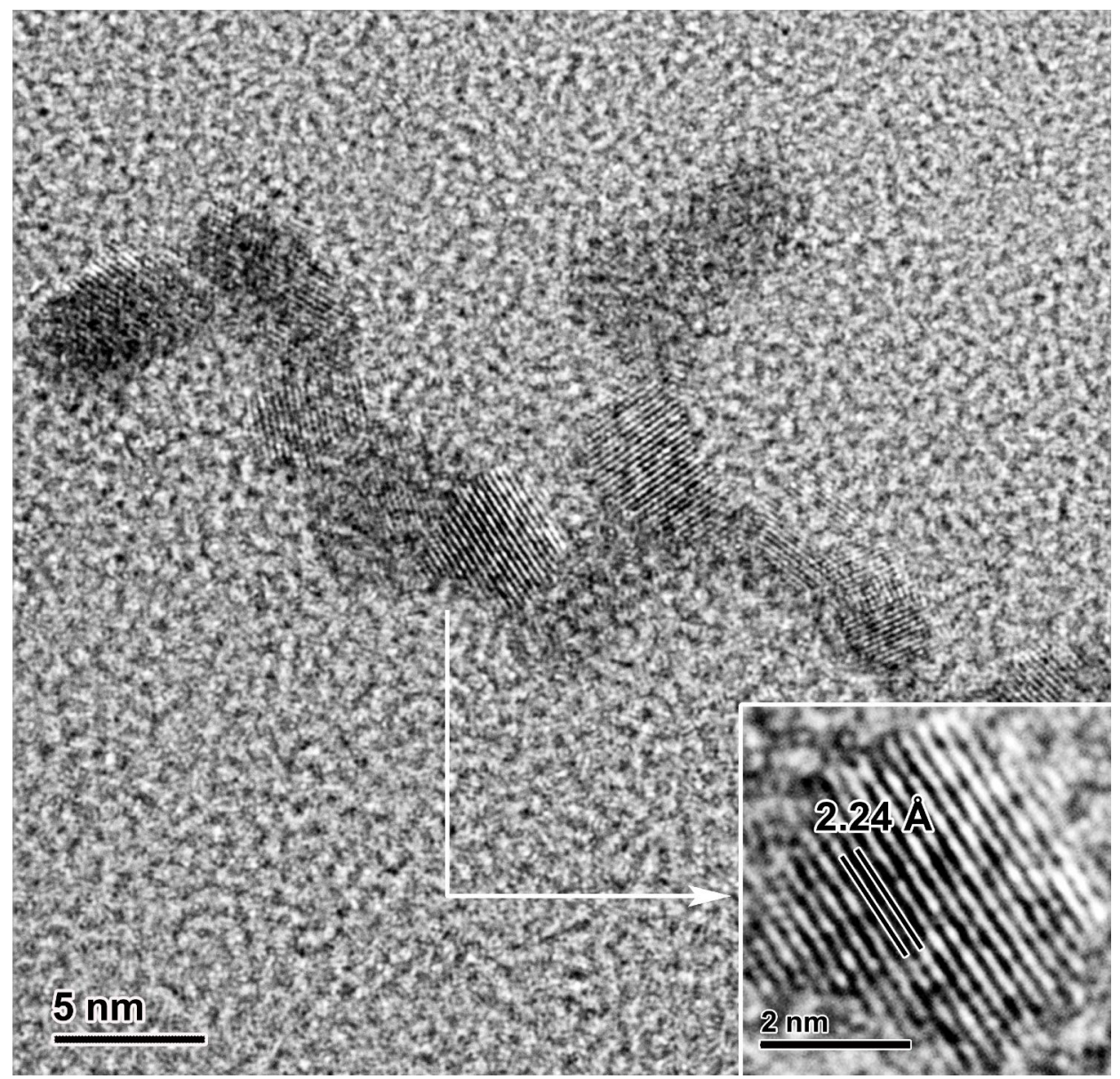

Figure S1. HRTEM image of the $\mathrm{Pt}_{1} \mathrm{Cu}_{0.84} \mathrm{Ni}_{0.11}$ ternary alloy nanowires. Inset: $\{111\}$ fringes of the alloy nanowires with $d$-spacing of $0.225 \mathrm{~nm}$. 

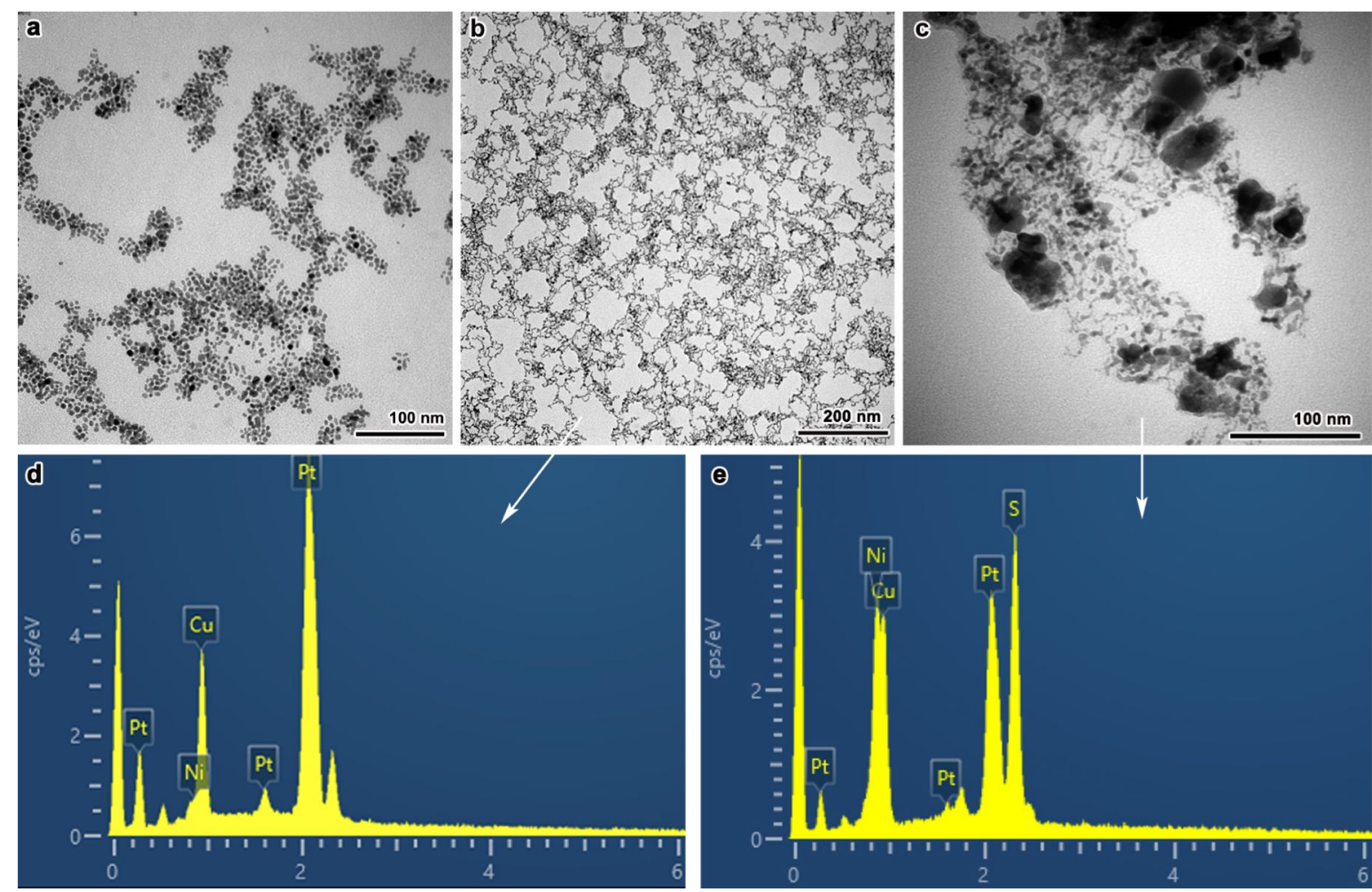

Figure S2. Analysis of the products obtained from a typical synthesis with different concentrations of sulfite. $(\mathrm{a}-\mathrm{c})$ TEM images of the products obtained without $\mathrm{Na}_{2} \mathrm{SO}_{3}$ and with $4 \mathrm{mM}$ and $6 \mathrm{mM}$ $\mathrm{Na}_{2} \mathrm{SO}_{3}$, respectively. (d, e) EDS spectra of the products obtained with $4 \mathrm{mM}$ and $6 \mathrm{mM} \mathrm{Na}_{2} \mathrm{SO}_{3}$, respectively. Instead of nanowires, only quasi-spherical nanoparticles can be obtained when $\mathrm{Na}_{2} \mathrm{SO}_{3}$ is absent from a typical synthesis. With a too high concentration of sulfite, copper and nickel sulfides emerge in the product, as evidenced by the large particles in the TEM image and high-intensity peaks of $\mathrm{S}, \mathrm{Cu}$, and $\mathrm{Ni}$ in the EDS spectrum. 


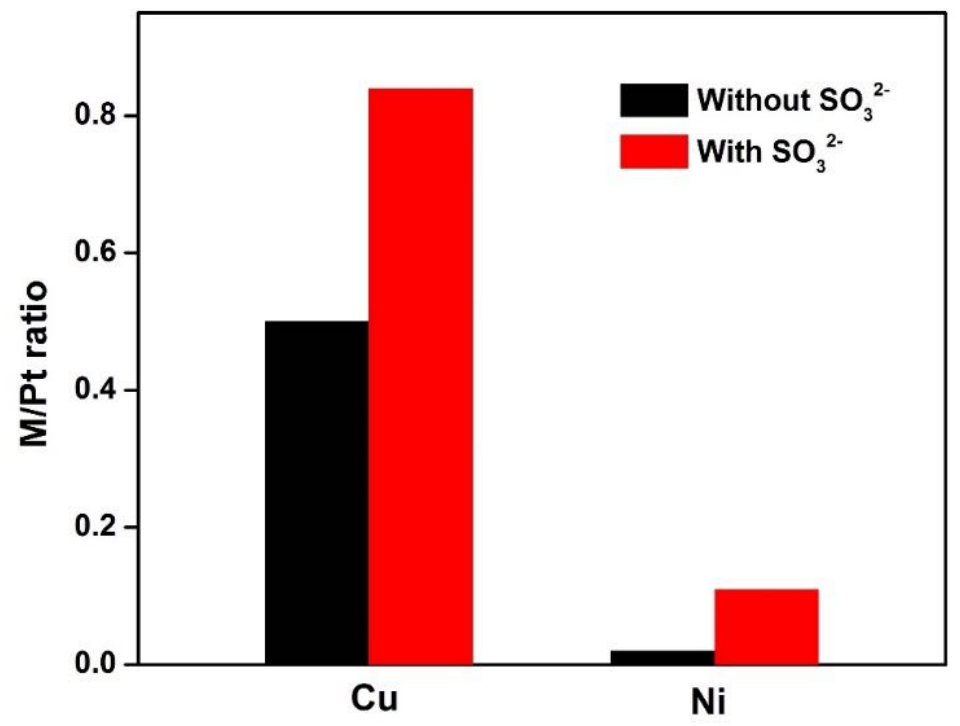

Figure S3. The $\mathrm{M} / \mathrm{Pt}(\mathrm{M}=\mathrm{Cu}, \mathrm{Ni})$ ratios in the products obtained from a typical synthesis with (red bars) and without the ligand of sulfite (black bars), measured by the ICP-MS. The results suggest that sulfite plays a crucial role in the effective co-reduction of the metal salts to afford Pt$\mathrm{Cu}-\mathrm{Ni}$ ternary alloy nanowires. 

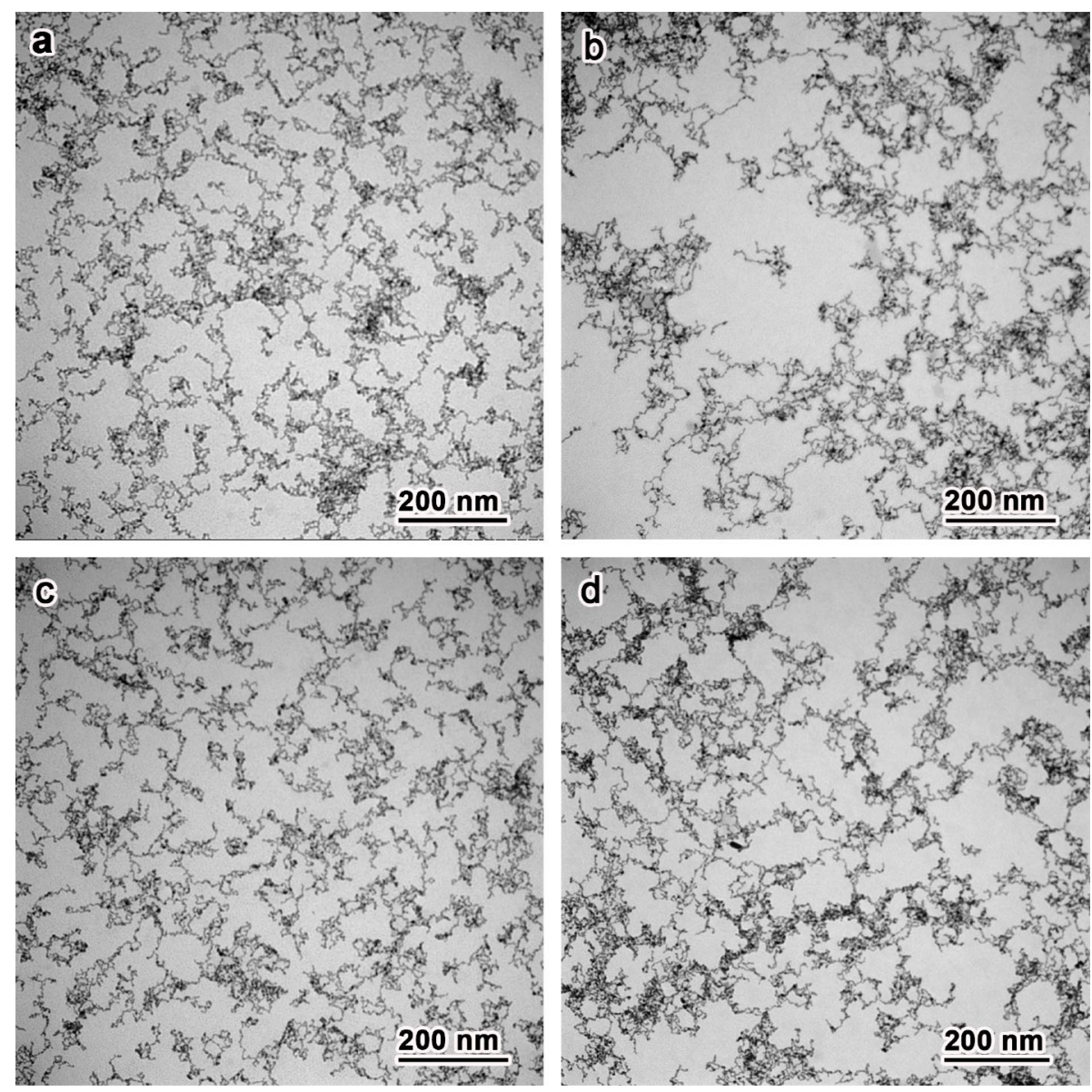

Figure S4. TEM images of the ultrathin Pt-Cu-Ni ternary alloy nanowires with different compositions: (a) $\mathrm{Pt}_{1} \mathrm{Cu}_{0.53} \mathrm{Ni}_{0.75}$, (b) $\mathrm{Pt}_{1} \mathrm{Cu}_{0.61} \mathrm{Ni}_{0.38}$, (c) $\mathrm{Pt}_{1} \mathrm{Cu}_{0.84} \mathrm{Ni}_{0.11}$, and (d) $\mathrm{Pt}_{1} \mathrm{Cu}_{2.05} \mathrm{Ni}_{0.04}$. 


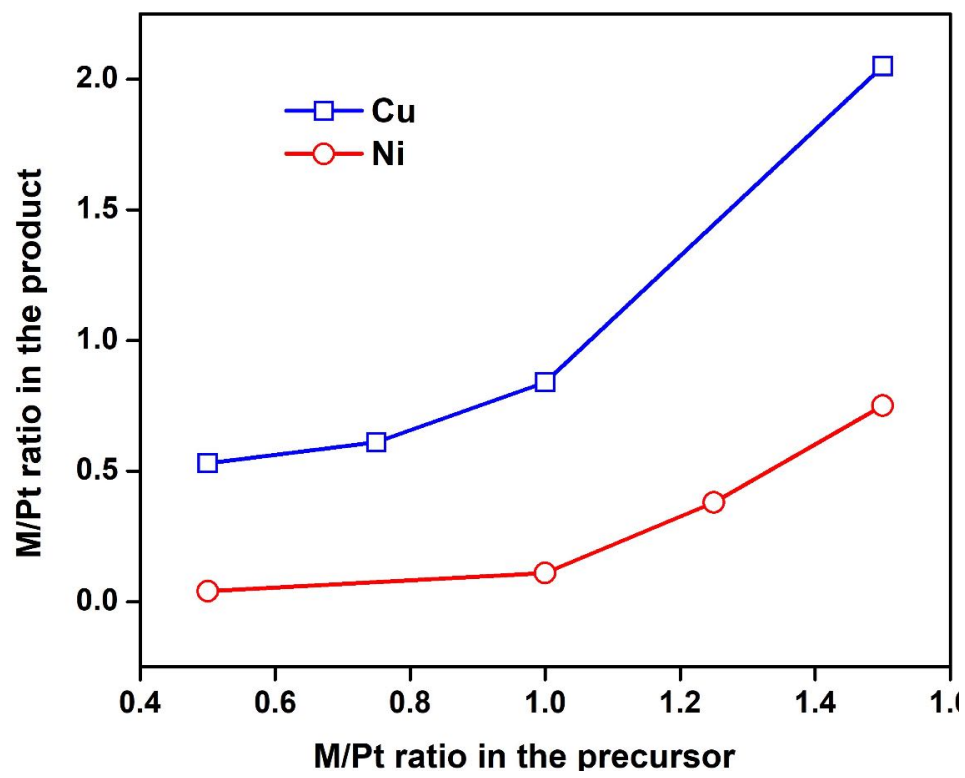

Figure S5. The plots of the $\mathrm{M} / \mathrm{Pt}$ ratios $(\mathrm{M}=\mathrm{Cu}, \mathrm{Ni})$ in the ultrathin Pt-Cu-Ni ternary alloy nanowires (measured by the ICP-MS) against the $\mathrm{M} / \mathrm{Pt}$ ratios in the precursors. 

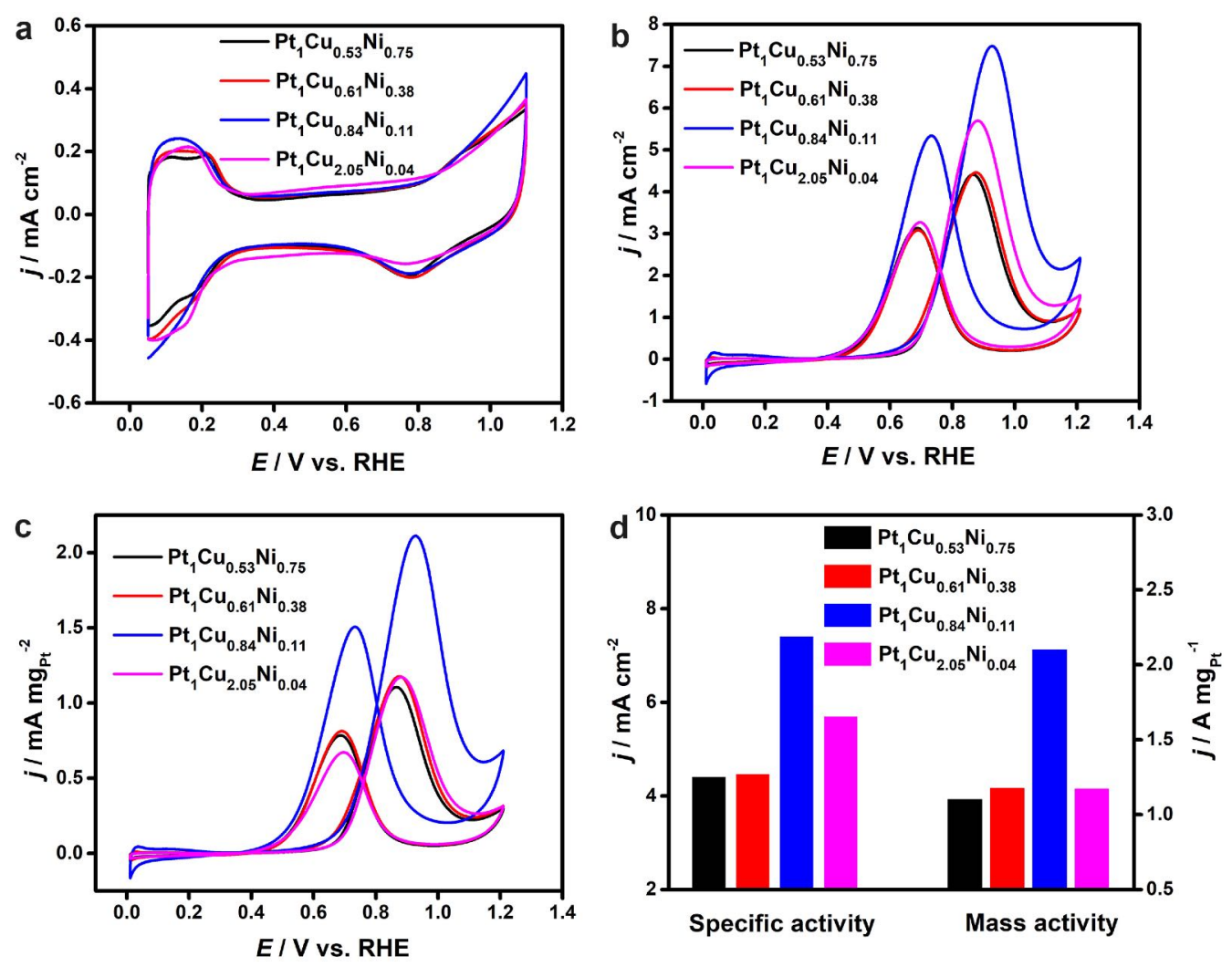

Figure S6. Electrocatalytic methanol oxidation performance of the $\mathrm{Pt}-\mathrm{Cu}-\mathrm{Ni}$ ternary alloy nanowires of different compositions. (a) $\mathrm{CV}$ curves of the Pt-Cu-Ni ternary alloy nanowires recorded in $\mathrm{N}_{2}$-saturated $0.5 \mathrm{M} \mathrm{H}_{2} \mathrm{SO}_{4}$ at a sweep rate of $50 \mathrm{mV} \mathrm{s}^{-1}$ at $25^{\circ} \mathrm{C}$. (b, c) MOR activities of the Pt-Cu-Ni ternary alloy nanowires. The $\mathrm{CV}$ curves were recorded in $\mathrm{N}_{2}$-saturated $0.5 \mathrm{M}$ $\mathrm{H}_{2} \mathrm{SO}_{4}+1 \mathrm{M} \mathrm{CH}_{3} \mathrm{OH}$ at a sweep rate of $50 \mathrm{mV} \mathrm{s}^{-1}$ at $25^{\circ} \mathrm{C}$. The current densities were normalized to the ECSA (b) and the mass of Pt (c), respectively. (d) A histogram summarizing the specific and mass activities of the Pt-Cu-Ni ternary alloy nanowires. 
Table S4. The specific activity, mass activity, and ECSAs of the Pt-Cu-Ni ternary alloy nanowires.

\begin{tabular}{cccc}
\hline Entry & $\begin{array}{c}\text { Mass activity } \\
\left(\mathrm{A} \mathrm{mg}^{-1}\right)\end{array}$ & $\begin{array}{c}\text { Specific activity } \\
\left(\mathrm{mA} \mathrm{cm}^{-2}\right)\end{array}$ & $\begin{array}{c}\text { ECSA } \\
\left(\mathrm{m}^{2} \mathrm{~g}^{-1}\right)\end{array}$ \\
\hline $\mathrm{Pt}_{1} \mathrm{Cu}_{0.53} \mathrm{Ni}_{0.75}$ & 1.1 & 4.4 & 25 \\
$\mathrm{Pt}_{1} \mathrm{Cu}_{0.61} \mathrm{Ni}_{0.38}$ & 1.17 & 4.46 & 26.2 \\
$\mathrm{Pt}_{1} \mathrm{Cu}_{2.05} \mathrm{Ni}_{0.04}$ & 1.2 & 5.6 & 21.4 \\
\hline
\end{tabular}



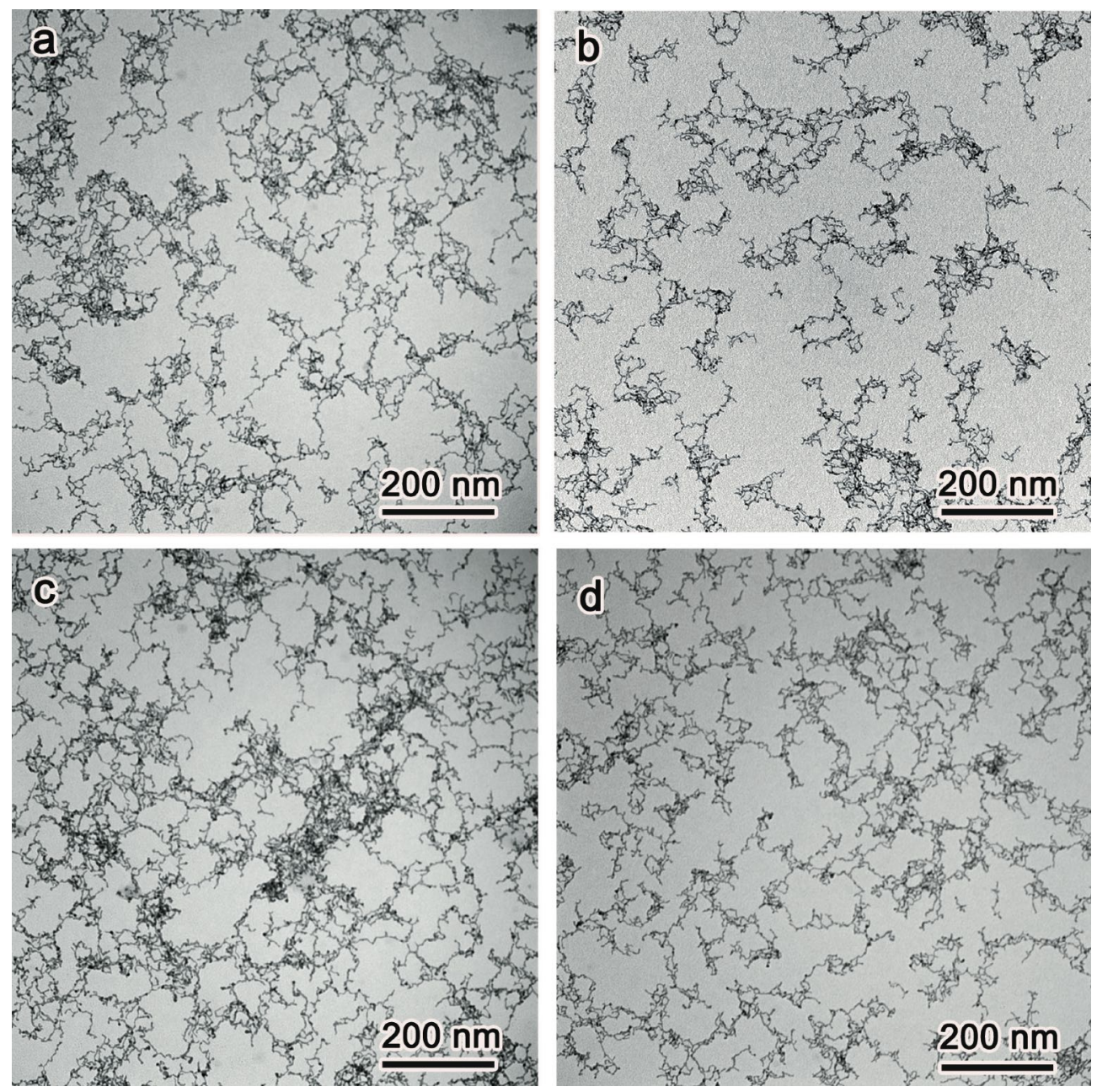

Figure S7. TEM images of the ultrathin Pt-Cu binary alloy nanowires of different compositions:

(a) $\mathrm{Pt}_{1} \mathrm{Cu}_{0.38}$, (b) $\mathrm{Pt}_{1} \mathrm{Cu}_{0.83}$, (c) $\mathrm{Pt}_{1} \mathrm{Cu}_{1.24}$, and (d) $\mathrm{Pt}_{1} \mathrm{Cu}_{1.33}$. 

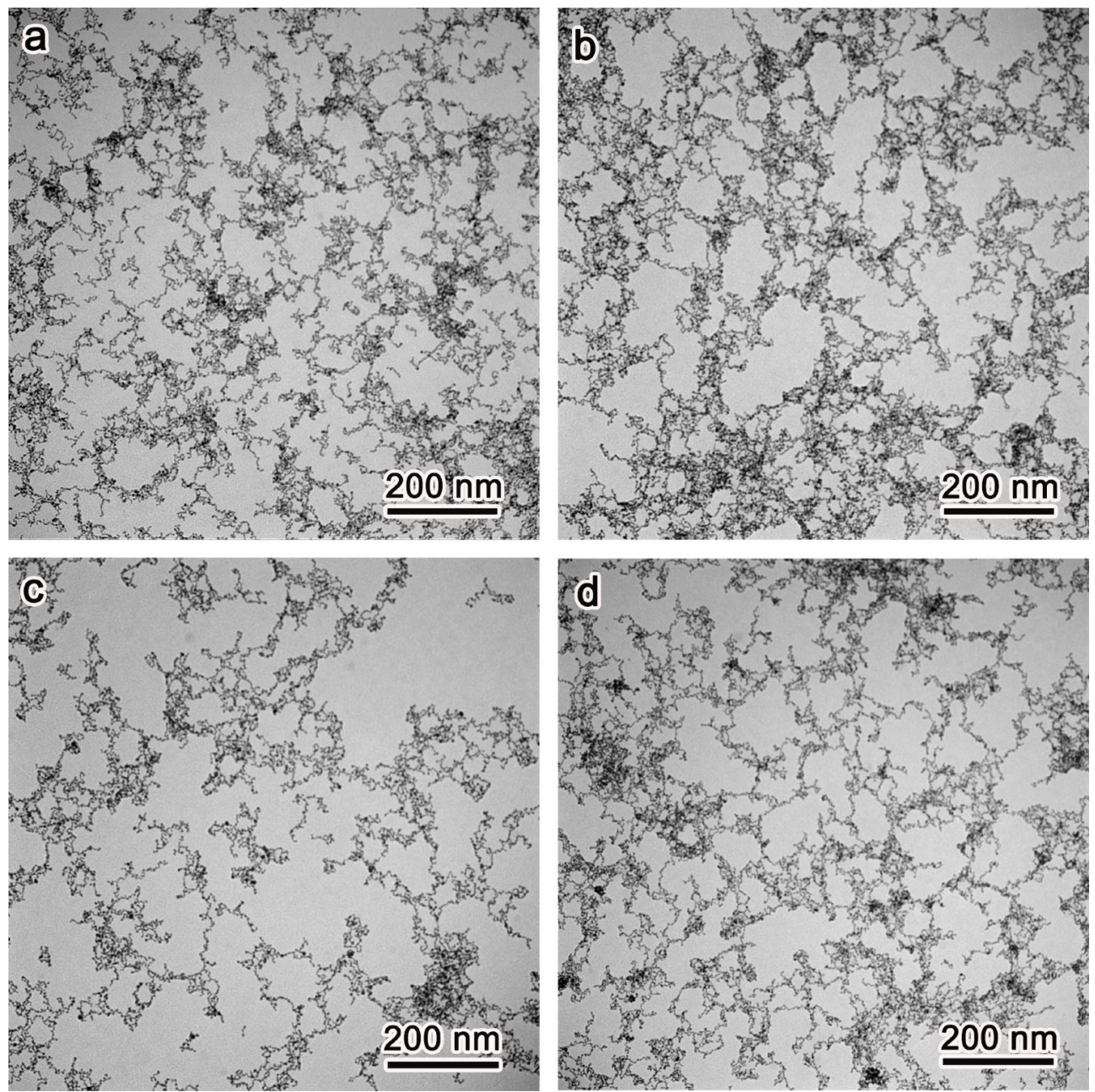

Figure S8. TEM images of the ultrathin Pt-Ni binary alloy nanowires of different compositions: (a) $\mathrm{Pt}_{1} \mathrm{Ni}_{0.09}$, (b) $\mathrm{Pt}_{1} \mathrm{Ni}_{0.2}$, (c) $\mathrm{Pt}_{1} \mathrm{Ni}_{0.28}$, and (d) $\mathrm{Pt}_{1} \mathrm{Ni}_{0.35}$. 


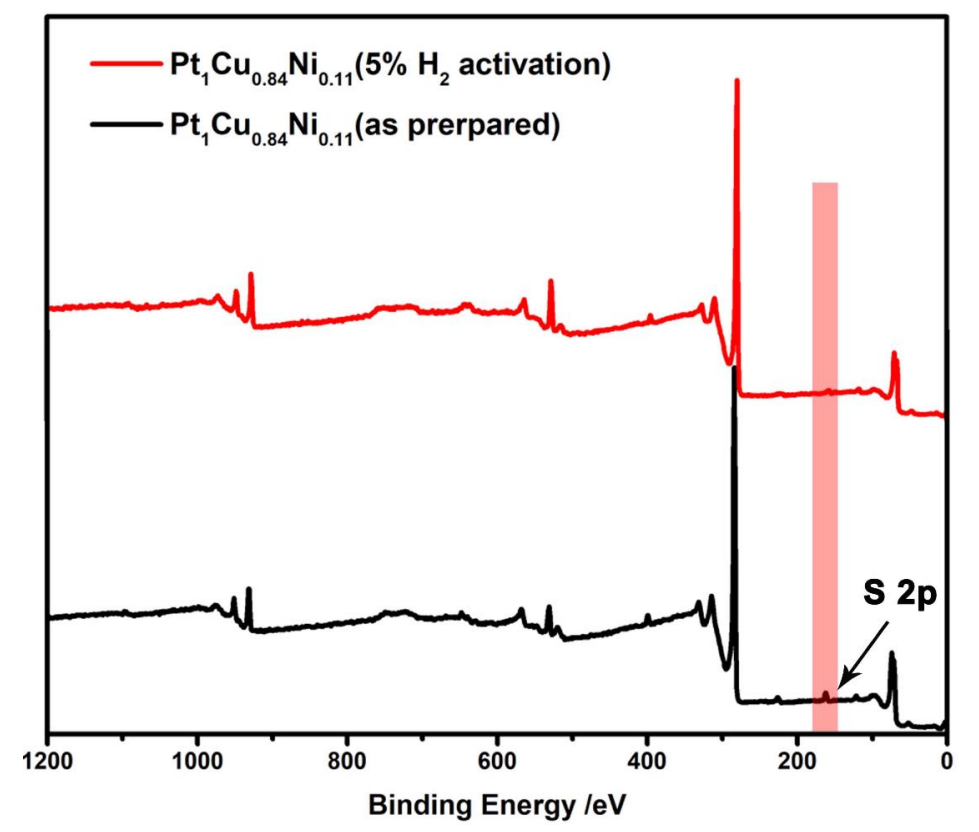

Figure S9. XPS spectra of the ultrathin $\mathrm{Pt}_{1} \mathrm{Cu}_{0.84} \mathrm{Ni}_{0.11}$ ternary alloy nanowires before and after the activation by $\mathrm{H}_{2}$. The red area represents the position of the $\mathrm{S} 2 \mathrm{p}$ peak. After activation, the sulfur contamination has been effectively removed from the surface of the nanowires. 

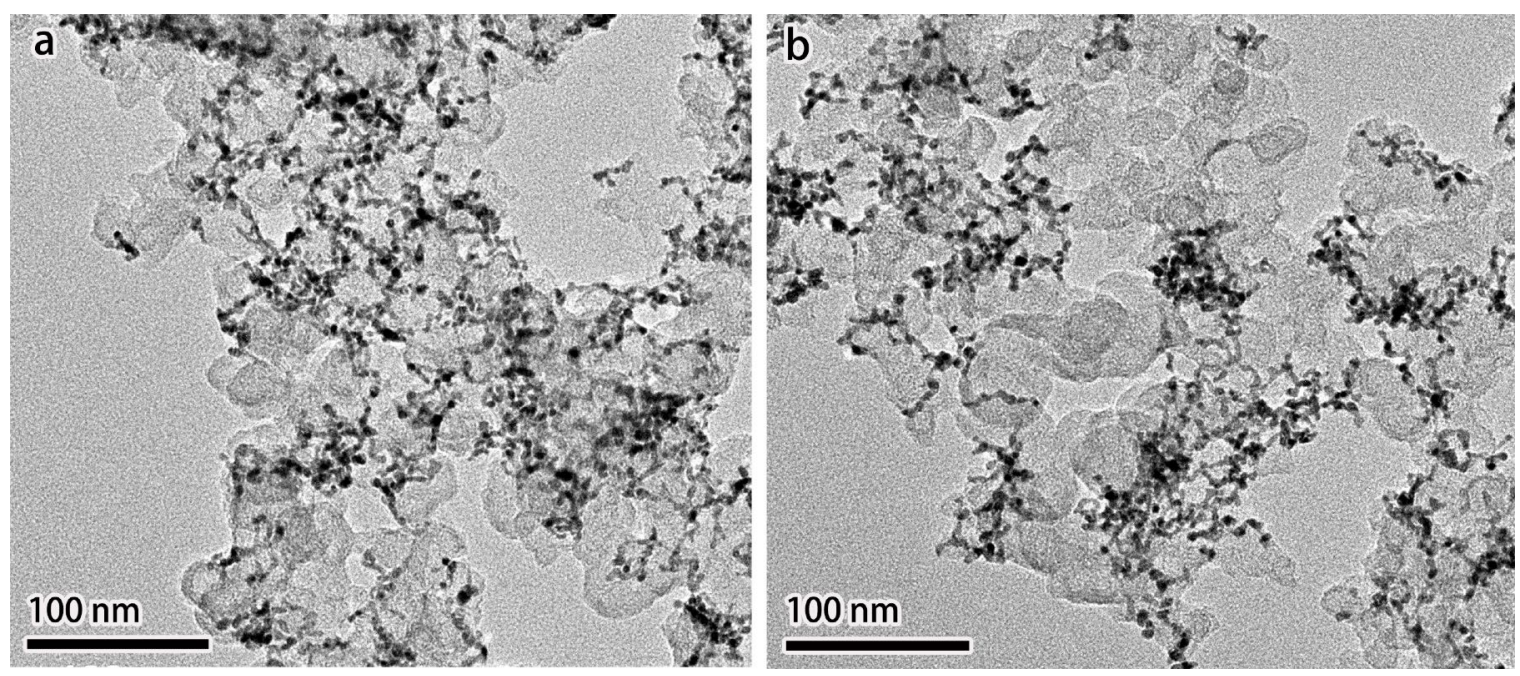

Figure S10. TEM images of the carbon-supported $\mathrm{Pt}_{1} \mathrm{Cu}_{0.84} \mathrm{Ni}_{0.11}$ ternary alloy nanowires before (a) and after activation by $\mathrm{H}_{2}$ (b). No obvious morphological changes can be observed during the activation treatment. 
Table S5. The alloy compositions of the Pt-Cu-Ni ternary alloy nanowires before and after activated by $\mathrm{H}_{2}$, measured by ICP-MS.

\begin{tabular}{ccc}
\hline & Before activation & After activation \\
\hline $\mathrm{Pt}-\mathrm{Cu}-\mathrm{Ni}$ & $\mathrm{Pt} / \mathrm{Cu} / \mathrm{Ni}=1: 0.84: 0.11$ & $\mathrm{Pt} / \mathrm{Cu} / \mathrm{Ni}=1: 0.85: 0.12$ \\
\hline
\end{tabular}

Discussion: No obvious changes in the alloy composition can be detected during the activation of the catalyst. 

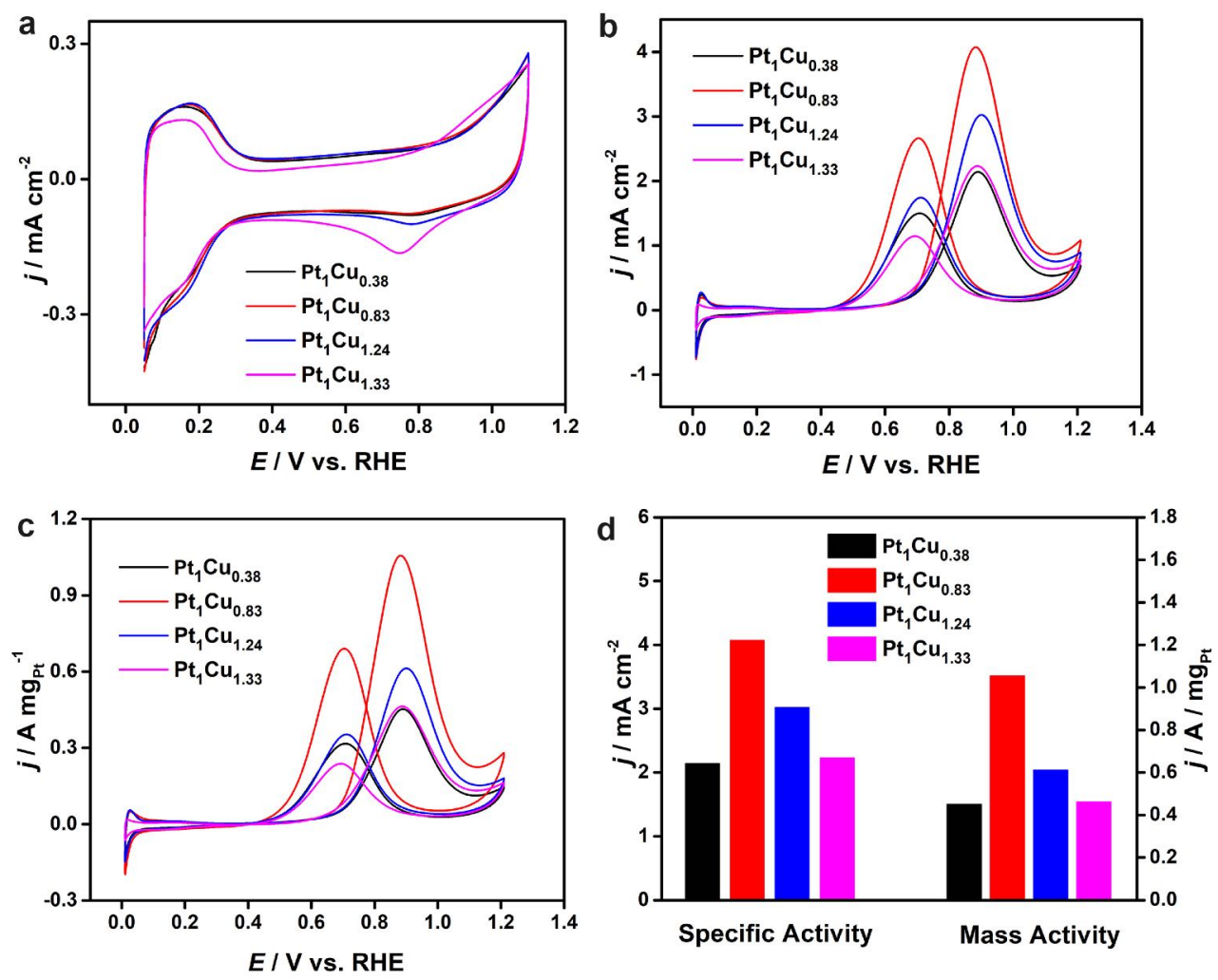

Figure S11. Electrocatalytic methanol oxidation performance of the Pt-Cu ternary alloy nanowires of different compositions. (a) $\mathrm{CV}$ curves of the Pt-Cu binary alloy nanowires recorded in $\mathrm{N}_{2}$ saturated $0.5 \mathrm{M} \mathrm{H}_{2} \mathrm{SO}_{4}$ at a sweep rate of $50 \mathrm{mV} \mathrm{s}^{-1}$ at $25{ }^{\circ} \mathrm{C}$. (b, c) MOR activities of the Pt-Cu binary alloy nanowires. The $\mathrm{CV}$ curves were recorded in $\mathrm{N}_{2}$-saturated $0.5 \mathrm{M} \mathrm{H}_{2} \mathrm{SO}_{4}+1 \mathrm{M} \mathrm{CH}_{3} \mathrm{OH}$ at a sweep rate of $50 \mathrm{mV} \mathrm{s}^{-1}$ at $25{ }^{\circ} \mathrm{C}$. The current densities are normalized to the ECSA (b) and the mass of $\mathrm{Pt}$ (c), respectively. (d) A histogram summarizing the specific and mass activities of the Pt-Cu binary alloy nanowires. 
Table S6. The specific activity, mass activity, and ECSAs of the Pt-Cu binary alloy nanowires.

\begin{tabular}{cccc}
\hline Entry & $\begin{array}{c}\text { Mass activity } \\
\left(\mathrm{A} \mathrm{mg}^{-1}\right)\end{array}$ & $\begin{array}{c}\text { Specific activity } \\
\left(\mathrm{mA} \mathrm{cm}^{-2}\right)\end{array}$ & $\begin{array}{c}\text { ECSA } \\
\left(\mathrm{m}^{2} \mathrm{~g}^{-1}\right)\end{array}$ \\
\hline $\mathrm{Pt}_{1} \mathrm{Cu}_{0.38}$ & 0.45 & 2.14 & 21.02 \\
$\mathrm{Pt}_{1} \mathrm{Cu}_{1.24}$ & 0.61 & 3.02 & 20.3 \\
$\mathrm{Pt}_{1} \mathrm{Cu}_{1.33}$ & 0.46 & 2.23 & 20.7 \\
\hline
\end{tabular}



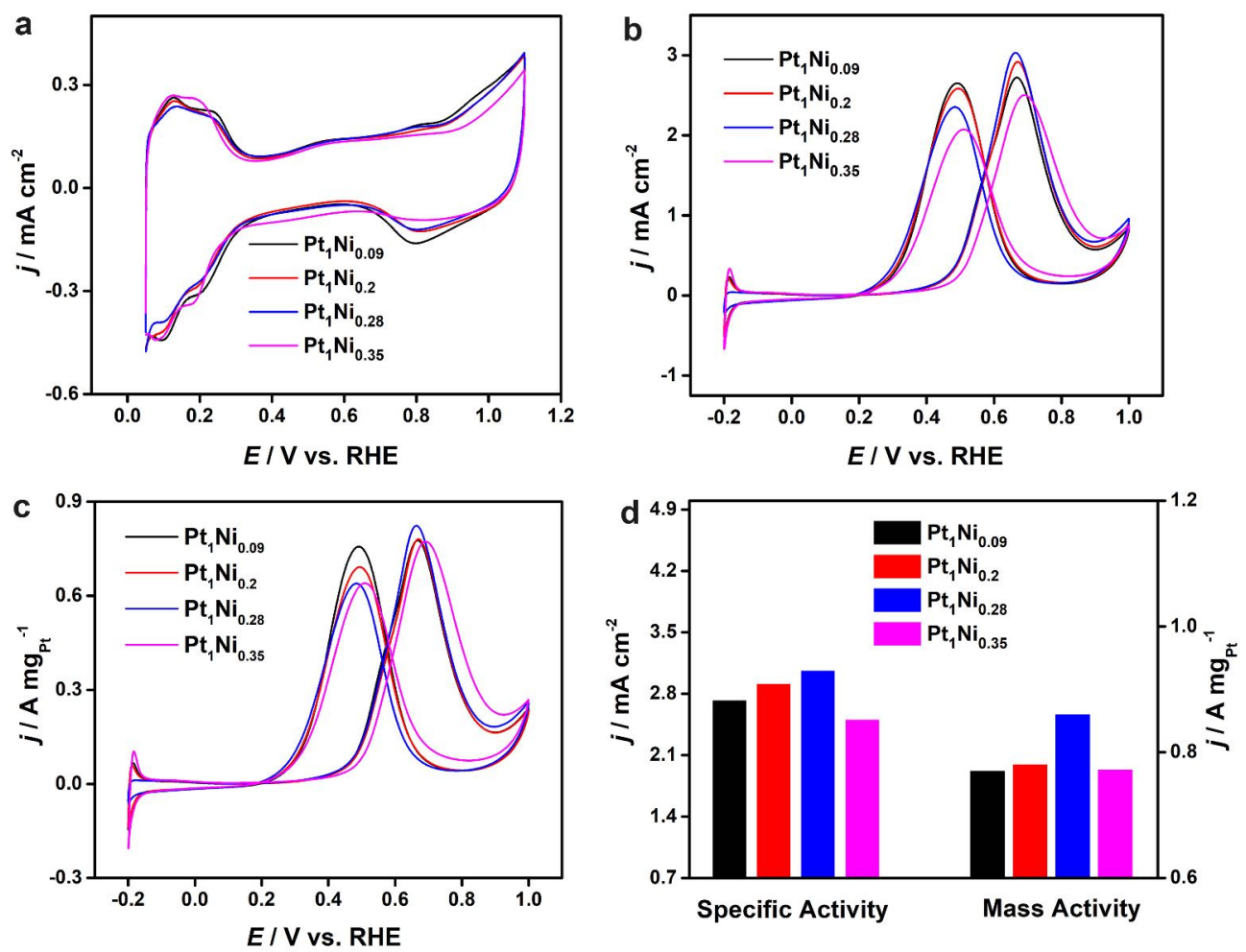

Figure S12. Electrocatalytic methanol oxidation performance of the Pt-Ni ternary alloy nanowires of different compositions. (a) CV curves of the Pt-Ni binary alloy nanowires recorded in $\mathrm{N}_{2}$ saturated $0.5 \mathrm{M} \mathrm{H}_{2} \mathrm{SO}_{4}$ at a sweep rate of $50 \mathrm{mV} \mathrm{s}^{-1}$ at $25{ }^{\circ} \mathrm{C}$. (b, c) MOR activities of the Pt-Ni binary alloy nanowires. The $\mathrm{CV}$ curves were recorded in $\mathrm{N}_{2}$-saturated $0.5 \mathrm{M} \mathrm{H}_{2} \mathrm{SO}_{4}+1 \mathrm{M} \mathrm{MeOH}$ at a sweep rate of $50 \mathrm{mV} \mathrm{s}^{-1}$ at $25{ }^{\circ} \mathrm{C}$. The current densities are normalized to the ECSA (b) and the mass of Pt (c), respectively. (d) A histogram summarizing the specific and mass activities of the Pt-Ni binary alloy nanowires. 
Table S7. The specific activity, mass activity, and ECSAs of the Pt-Ni binary alloy nanowires.

\begin{tabular}{cccc}
\hline Entry & $\begin{array}{c}\text { Mass activity } \\
\left(\mathrm{A} \mathrm{mg}^{-1}\right)\end{array}$ & $\begin{array}{r}\text { Specific activity } \\
(\mathrm{mA} \mathrm{cm})^{-2}\end{array}$ & $\begin{array}{c}\text { ECSA } \\
\left(\mathrm{m}^{2} \mathrm{~g}^{-1}\right)\end{array}$ \\
\hline $\mathrm{Pt}_{1} \mathrm{Ni}_{0.09}$ & 0.77 & 2.72 & 28.3 \\
$\mathrm{Pt}_{1} \mathrm{Ni}_{0.2}$ & 0.78 & 2.91 & 26.8 \\
$\mathrm{Pt}_{1} \mathrm{Ni}_{0.35}$ & 0.76 & 2.5 & 30 \\
\hline
\end{tabular}




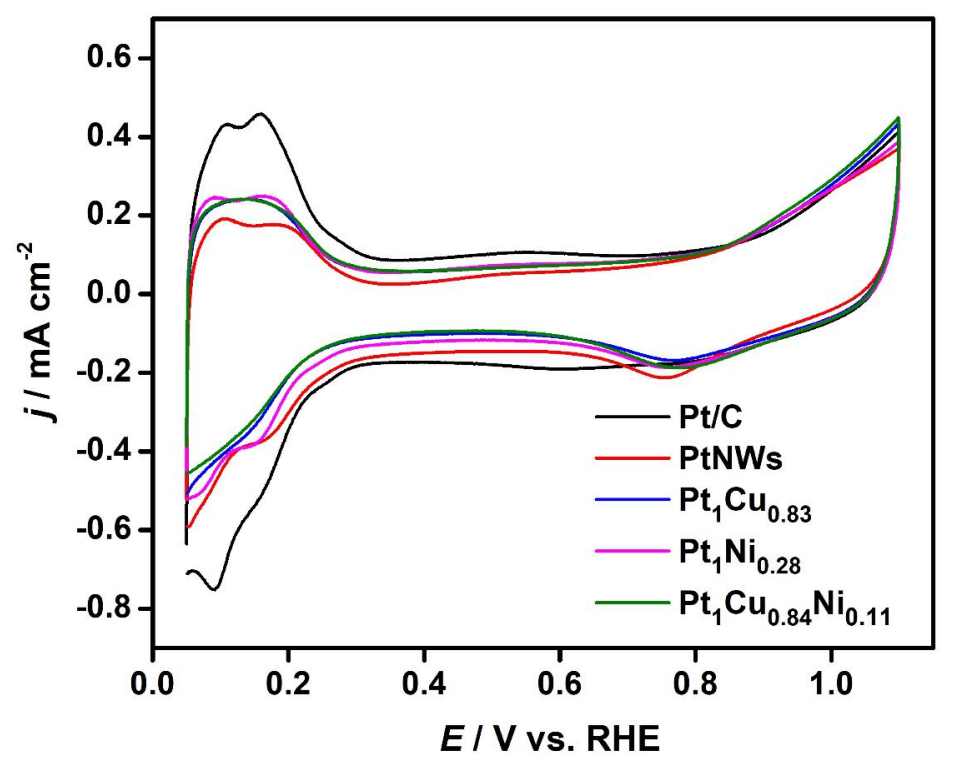

Figure S13. $\mathrm{CV}$ curves of the $\mathrm{Pt}, \mathrm{Pt}_{1} \mathrm{Cu}_{0.83}, \mathrm{Pt}_{1} \mathrm{Ni}_{0.28}$, and $\mathrm{Pt}_{1} \mathrm{Cu}_{0.84} \mathrm{Ni}_{0.11}$ nanowires and the commercial Pt/C recorded in $\mathrm{N}_{2}$-saturated $0.5 \mathrm{M} \mathrm{H}_{2} \mathrm{SO}_{4}$ at a sweep rate of $50 \mathrm{mV} \mathrm{s}^{-1}$. The ECSAs of the $\mathrm{Pt}, \mathrm{Pt}_{1} \mathrm{Cu}_{0.83}, \mathrm{Pt}_{1} \mathrm{Ni}_{0.28}$, and $\mathrm{Pt}_{1} \mathrm{Cu}_{0.84} \mathrm{Ni}_{0.11}$ nanowires, and the commercial $\mathrm{Pt} / \mathrm{C}$ were 25.6, $27.7,28.0,28.4$, and $51.1 \mathrm{~m}^{2} \mathrm{~g}^{-1}$, respectively, according to the charges associated with the hydrogen adsorption in the range of $0.05-0.4 \mathrm{~V}$ after the double layer correction. 
Table S8. Catalytic performance of typical Pt-based catalysts for the MOR reported in the literature.

\begin{tabular}{|c|c|c|c|c|c|}
\hline Catalysts & Conditions & $\begin{array}{c}\text { Specific } \\
\text { activity } \\
\left(\mathrm{mA} \mathrm{cm}^{-2}\right)\end{array}$ & $\begin{array}{c}\text { Mass } \\
\text { activity } \\
\left(\mathrm{A} \mathrm{mg}^{-1}\right)\end{array}$ & $\begin{array}{l}\text { ECSA } \\
\left(\mathrm{m}^{2} \mathrm{~g}^{-1}\right)\end{array}$ & Ref. \\
\hline $\begin{array}{l}\mathrm{Pt}-\mathrm{Cu}-\mathrm{Ni} \text { alloy } \\
\text { nanowires }\end{array}$ & $\begin{array}{l}0.5 \mathrm{M} \mathrm{H}_{2} \mathrm{SO}_{4}+ \\
1 \mathrm{M} \mathrm{CH}_{3} \mathrm{OH}\end{array}$ & 7.4 & 2.1 & 28 & $\begin{array}{l}\text { This } \\
\text { work }\end{array}$ \\
\hline $\begin{array}{l}\text { Ce-modified Pt } \\
\text { NPs/C }\end{array}$ & $\begin{array}{l}0.5 \mathrm{M} \mathrm{H}_{2} \mathrm{SO}_{4}+ \\
1 \mathrm{M} \mathrm{CH}_{3} \mathrm{OH}\end{array}$ & 1.2 & 1.47 & & 8 \\
\hline $\begin{array}{l}\text { 2D PdFePt } \\
\text { nanomeshes }\end{array}$ & $\begin{array}{l}0.1 \mathrm{M} \mathrm{HClO}_{4}+ \\
0.5 \mathrm{M} \mathrm{CH}_{3} \mathrm{OH}\end{array}$ & 4.36 & 1.61 & & 9 \\
\hline PtNiRh nanowires & $\begin{array}{l}0.1 \mathrm{M} \mathrm{HClO}_{4}+ \\
1.0 \mathrm{M} \mathrm{CH}_{3} \mathrm{OH}\end{array}$ & 2.49 & 1.72 & 69 & 10 \\
\hline $\begin{array}{l}\text { Pt-Ag alloy } \\
\text { octahedra }\end{array}$ & $\begin{array}{l}0.1 \mathrm{M} \mathrm{HClO}_{4}+ \\
0.5 \mathrm{M} \mathrm{CH}_{3} \mathrm{OH}\end{array}$ & 6.61 & 0.726 & & 11 \\
\hline $\begin{array}{l}\text { PtFe@PtRuFe core- } \\
\text { shell nanostructure }\end{array}$ & $\begin{array}{l}0.1 \mathrm{M} \mathrm{HClO}_{4}+ \\
0.5 \mathrm{M} \mathrm{CH}_{3} \mathrm{OH}\end{array}$ & 1.3 & 0.69 & & 12 \\
\hline $\begin{array}{l}\text { CoPtAu } \\
\text { nanoparticles }\end{array}$ & $\begin{array}{l}0.1 \mathrm{M} \mathrm{HClO}_{4}+ \\
2 \mathrm{M} \mathrm{CH}_{3} \mathrm{OH}\end{array}$ & & 1.49 & & 13 \\
\hline $\begin{array}{l}\text { Porous ultrathin Pt- } \\
\text { Ag nanotubes }\end{array}$ & $\begin{array}{l}0.1 \mathrm{M} \mathrm{HClO}_{4}+ \\
1.0 \mathrm{M} \mathrm{CH}_{3} \mathrm{OH}\end{array}$ & 6.63 & 2.08 & 31.3 & 14 \\
\hline $\begin{array}{l}\text { PtNi colloidal } \\
\text { nanocrystal clusters }\end{array}$ & $\begin{array}{l}0.5 \mathrm{M} \mathrm{H}_{2} \mathrm{SO}_{4}+ \\
0.5 \mathrm{M} \mathrm{CH}_{3} \mathrm{OH}\end{array}$ & 6.96 & 1.37 & 51 & 15 \\
\hline $\begin{array}{l}\text { Ultrathin Pt-Zn } \\
\text { nanowires }\end{array}$ & $\begin{array}{l}0.5 \mathrm{M} \mathrm{H}_{2} \mathrm{SO}_{4}+ \\
0.5 \mathrm{M} \mathrm{CH}_{3} \mathrm{OH}\end{array}$ & 3.48 & 1.005 & & 16 \\
\hline $\begin{array}{l}\text { Atomic } \mathrm{Pt} \text { on } \\
\text { intermetallic } \mathrm{Pt}_{3} \mathrm{Ga}\end{array}$ & $\begin{array}{l}0.5 \mathrm{M} \mathrm{H}_{2} \mathrm{SO}_{4}+ \\
1.0 \mathrm{M} \mathrm{CH}_{3} \mathrm{OH}\end{array}$ & 7.195 & 1.094 & & 17 \\
\hline $\begin{array}{l}h c p-\mathrm{PtBi} / f_{c c} \text {-Pt core- } \\
\text { shell nanoparticles }\end{array}$ & $\begin{array}{l}0.1 \mathrm{M} \mathrm{HClO}_{4}+ \\
0.1 \mathrm{M} \mathrm{CH}_{3} \mathrm{OH}\end{array}$ & 3.18 & 1.1 & & 18 \\
\hline Pt-Ru nanowires & $\begin{array}{l}0.1 \mathrm{M} \mathrm{HClO}_{4}+ \\
0.5 \mathrm{M} \mathrm{CH}_{3} \mathrm{OH}\end{array}$ & 1.16 & 0.82 & 72.1 & 19 \\
\hline $\begin{array}{l}\mathrm{Pt}_{72} \mathrm{Ru}_{28} \text { porous } \\
\text { nanoalloy }\end{array}$ & $\begin{array}{l}0.1 \mathrm{M} \mathrm{HClO}_{4}+ \\
0.5 \mathrm{M} \mathrm{CH}_{3} \mathrm{OH}\end{array}$ & 10.98 & 1.7 & & 20 \\
\hline $\begin{array}{l}\text { Open-structured } \\
\mathrm{PtCu} \text { nanotubes }\end{array}$ & $\begin{array}{l}0.5 \mathrm{M} \mathrm{H}_{2} \mathrm{SO}_{4}+ \\
1.0 \mathrm{M} \mathrm{CH}_{3} \mathrm{OH}\end{array}$ & 6.09 & 2.252 & 38 & 21 \\
\hline $\begin{array}{l}\mathrm{Pt}_{17} \mathrm{Pd}_{16} \mathrm{Ru}_{22} \mathrm{Te}_{45} \\
\text { nanotubes }\end{array}$ & $\begin{array}{l}0.5 \mathrm{M} \mathrm{H}_{2} \mathrm{SO}_{4}+ \\
1.0 \mathrm{M} \mathrm{CH}_{3} \mathrm{OH}\end{array}$ & 2.96 & 1.26 & & 22 \\
\hline
\end{tabular}




\begin{tabular}{|c|c|c|c|c|c|}
\hline $\begin{array}{l}\text { Concave } \mathrm{PtCu}_{2} \\
\text { octopod nanoframes }\end{array}$ & $\begin{array}{l}0.5 \mathrm{M} \mathrm{H}_{2} \mathrm{SO}_{4}+ \\
1.0 \mathrm{M} \mathrm{CH}_{3} \mathrm{OH}\end{array}$ & 7.5 & 3.356 & 44.5 & 23 \\
\hline $\mathrm{PtZn/MWNTs}$ & $\begin{array}{l}0.5 \mathrm{M} \mathrm{H}_{2} \mathrm{SO}_{4}+ \\
1.0 \mathrm{M} \mathrm{CH}_{3} \mathrm{OH}\end{array}$ & 1.08 & 0.612 & & 24 \\
\hline $\begin{array}{l}\mathrm{Pt}-\mathrm{Pb} \text { concave } \\
\text { nanocubes }\end{array}$ & $\begin{array}{l}0.1 \mathrm{M} \mathrm{HClO}_{4}+ \\
0.5 \mathrm{M} \mathrm{CH}_{3} \mathrm{OH}\end{array}$ & 2.09 & 0.97 & 46.6 & 25 \\
\hline Pt nanowires & $\begin{array}{l}0.1 \mathrm{M} \mathrm{HClO}_{4}+ \\
0.1 \mathrm{M} \mathrm{CH}_{3} \mathrm{OH}\end{array}$ & 5.84 & 1.312 & 21.5 & 26 \\
\hline $\begin{array}{l}\text { Screw thread-like } \\
\mathrm{PtCu}_{2.1} \text { nanowires }\end{array}$ & $\begin{array}{l}0.1 \mathrm{M} \mathrm{HClO}_{4}+ \\
0.2 \mathrm{M} \mathrm{CH}_{3} \mathrm{OH}\end{array}$ & 3.1 & 1.56 & 46.9 & 27 \\
\hline $\begin{array}{l}\mathrm{PtRu} / \mathrm{TiWC} \\
\text { nanoparticles }\end{array}$ & $\begin{array}{l}0.1 \mathrm{M} \mathrm{HClO}_{4}+ \\
1.0 \mathrm{M} \mathrm{CH}_{3} \mathrm{OH}\end{array}$ & 1.8 & & $68 \pm 6$ & 28 \\
\hline PtCo nanowires & $\begin{array}{l}0.1 \mathrm{M} \mathrm{HClO}_{4}+ \\
0.2 \mathrm{M} \mathrm{CH}_{3} \mathrm{OH}\end{array}$ & 1.95 & 1.02 & 52.1 & 29 \\
\hline $\mathrm{PtPb} / \mathrm{Pt}$ nanoplates & $\begin{array}{l}0.1 \mathrm{M} \mathrm{HClO}_{4}+ \\
0.1 \mathrm{M} \mathrm{CH}_{3} \mathrm{OH}\end{array}$ & 2.6 & 1.5 & 55 & 30 \\
\hline $\begin{array}{l}\text { THH Pt-Ni NFs/C } \\
\text { RDH }\end{array}$ & $\begin{array}{l}0.1 \mathrm{M} \mathrm{HClO}_{4}+ \\
0.2 \mathrm{M} \mathrm{CH}_{3} \mathrm{OH}\end{array}$ & 2.19 & 0.4 & 46.3 & 31 \\
\hline $\mathrm{Pt}-\mathrm{Ni} \mathrm{NFs} / \mathrm{C}$ & $\begin{array}{l}0.1 \mathrm{M} \mathrm{HClO}_{4}+ \\
0.2 \mathrm{M} \mathrm{CH}_{3} \mathrm{OH}\end{array}$ & 1.9 & 1.04 & 54.6 & 31 \\
\hline
\end{tabular}




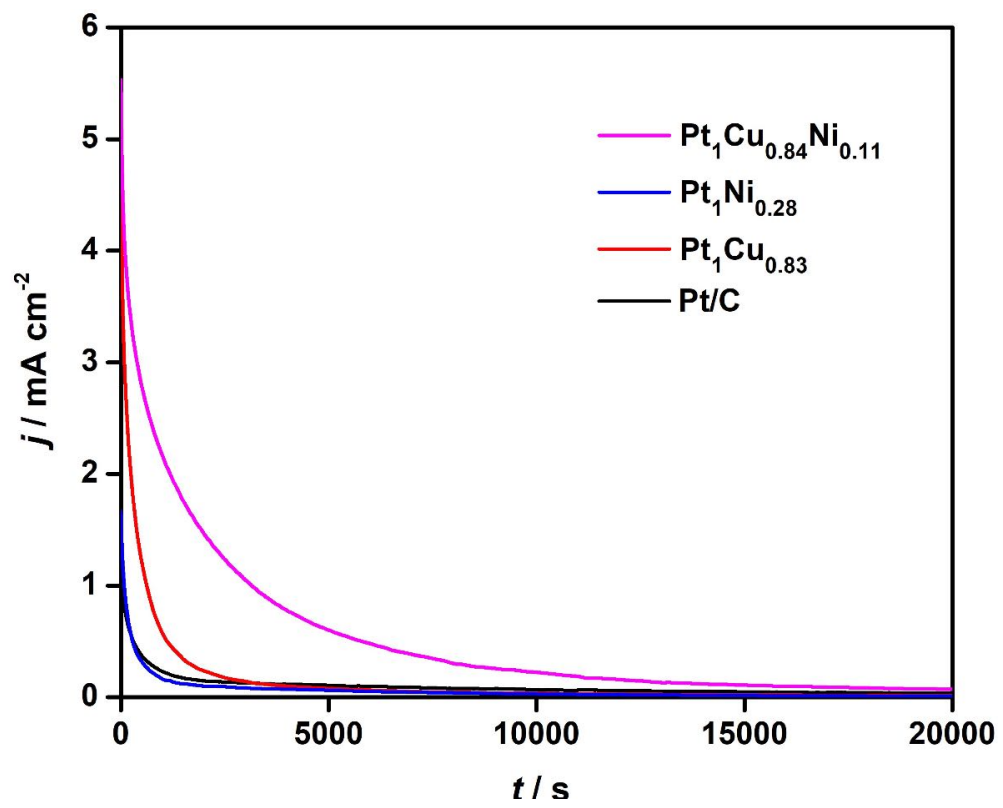

Figure S14. Chronoamperometric $i-t$ curves of the catalysts $\left(\mathrm{Pt}_{1} \mathrm{Cu}_{0.83}, \mathrm{Pt}_{1} \mathrm{Ni}_{0.28}, \mathrm{Pt}_{1} \mathrm{Cu}_{0.84} \mathrm{Ni}_{0.11}\right.$, and the $\mathrm{Pt} / \mathrm{C}$ ) measured at $0.8 \mathrm{~V}$ vs. $\mathrm{RHE}$ in $0.5 \mathrm{M} \mathrm{H}_{2} \mathrm{SO}_{4}+1 \mathrm{M} \mathrm{CH}_{3} \mathrm{OH}$ for $20000 \mathrm{~s}$. 

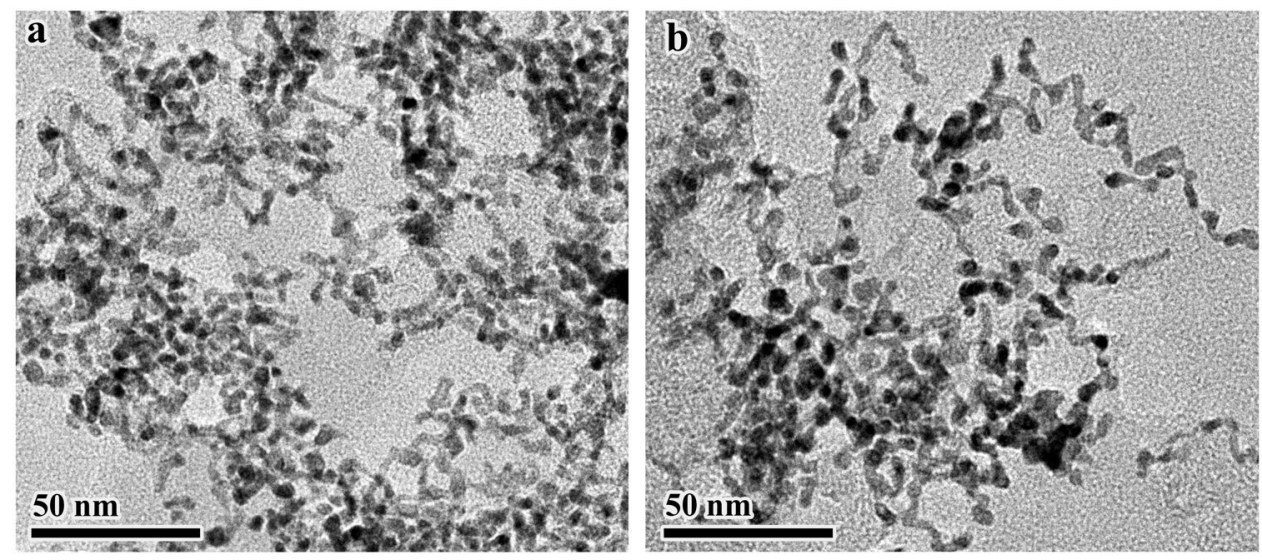

Figure S15. TEM images of the $\mathrm{Pt}_{1} \mathrm{Cu}_{0.84} \mathrm{Ni}_{0.11} / \mathrm{C}$ ternary alloy nanowires before (a) and after the chronoamperometric $i$ - $t$ durability test for $20,000 \mathrm{~s}(\mathrm{~b})$. 


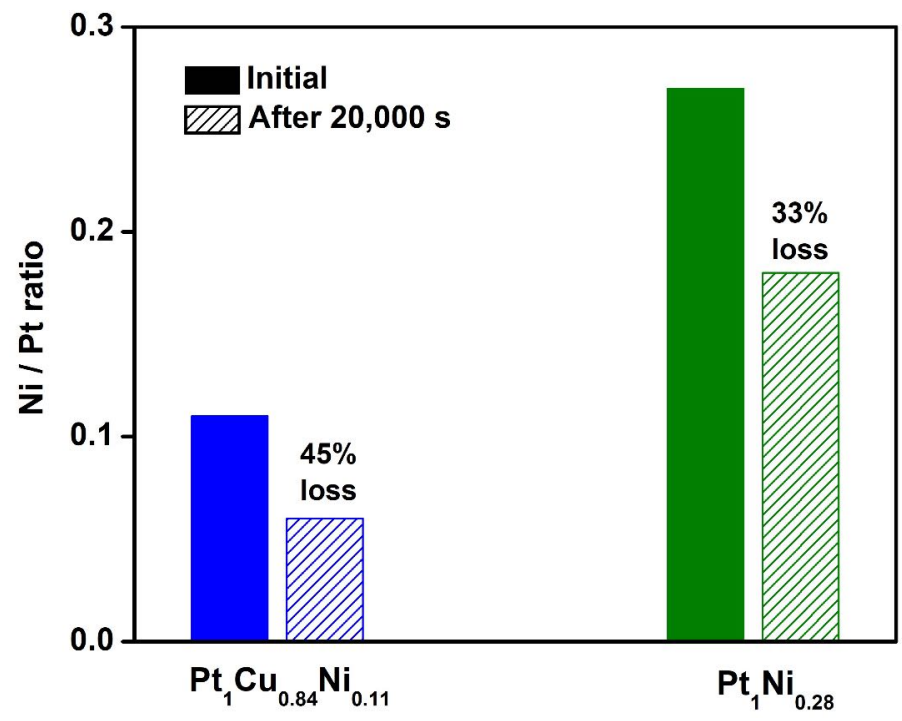

Figure S16. The Ni/Pt ratio of the $\mathrm{Pt}_{1} \mathrm{Cu}_{0.84} \mathrm{Ni}_{0.11}$ and $\mathrm{Pt}_{1} \mathrm{Ni}_{0.28}$ alloy nanowires before and after the chronoamperometric $i-t$ durability test, measured by the ICP-MS. 

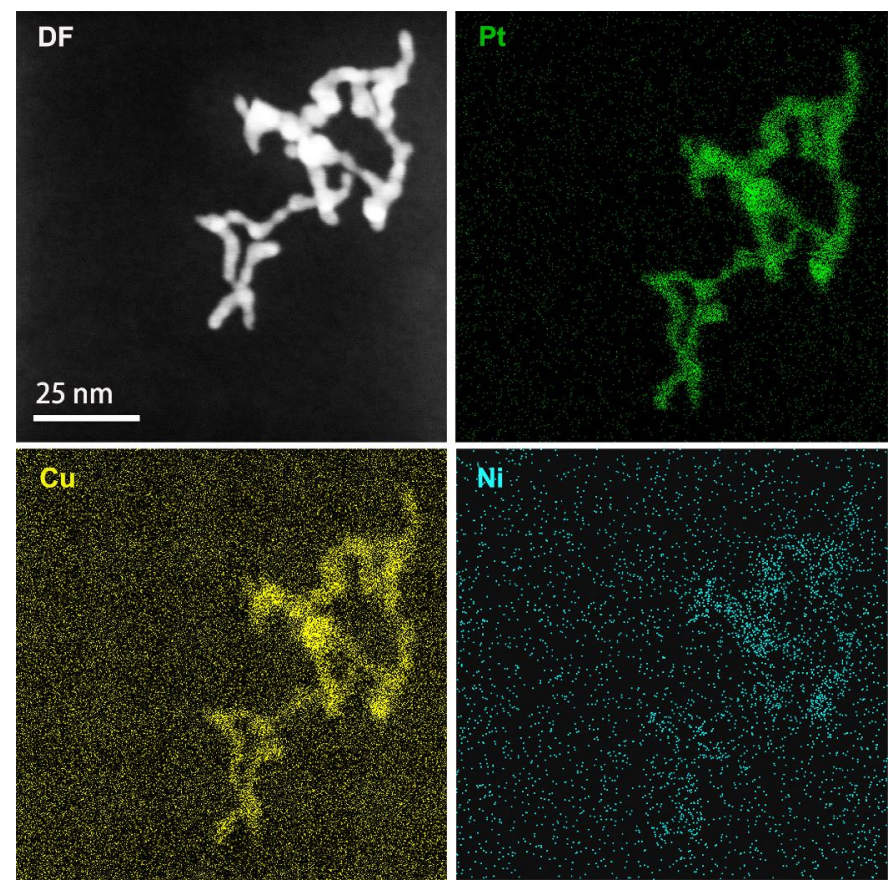

Figure S17. EDS mapping of the $\mathrm{Pt}_{1} \mathrm{Cu}_{0.84} \mathrm{Ni}_{0.11}$ ternary alloy nanowires after the chronoamperometric $i$ - $t$ durability test for $20,000 \mathrm{~s}$. 
Table S9. Compositions of the alloy nanowires before and after the CV tests for 300 cycles.

\begin{tabular}{c|ccc|ccc}
\hline \multirow{2}{*}{ Entry } & \multicolumn{3}{|c|}{ Before CV } & \multicolumn{3}{c}{ After CV } \\
\cline { 2 - 7 } & $\mathrm{Pt}$ & $\mathrm{Cu}$ & $\mathrm{Ni}$ & $\mathrm{Pt}$ & $\mathrm{Cu}$ & $\mathrm{Ni}$ \\
\hline $\mathrm{Pt}_{1} \mathrm{Cu}_{0.84} \mathrm{Ni}_{0.11}$ & 1 & 0.84 & 0.11 & 1 & 0.8 & 0.09 \\
$\mathrm{Pt}_{1} \mathrm{Cu}_{0.83}$ & 1 & 0.83 & - & 1 & 0.76 & - \\
$\mathrm{Pt}_{1} \mathrm{Ni}_{0.28}$ & 1 & - & 0.28 & 1 & - & 0.26 \\
\hline
\end{tabular}




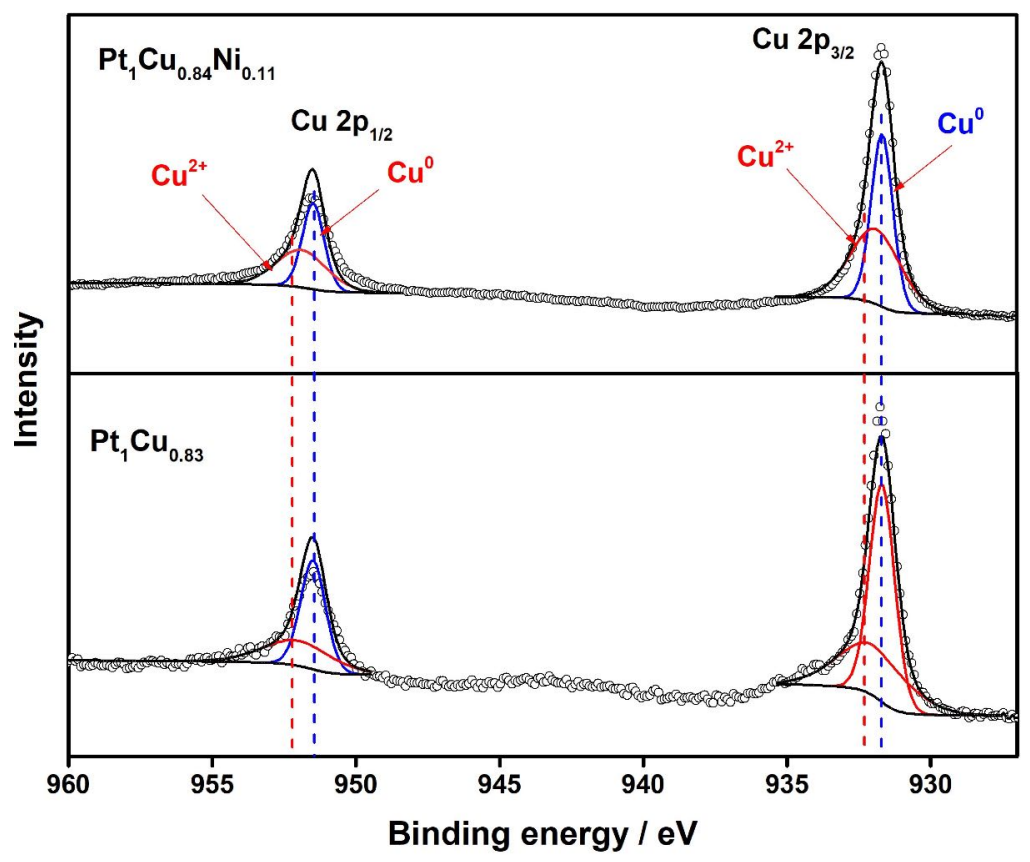

Figure S18. $\mathrm{Cu} 2 \mathrm{p}$ XPS spectra of the $\mathrm{Pt}_{1} \mathrm{Cu}_{0.83}$ and the $\mathrm{Pt}_{1} \mathrm{Cu}_{0.84} \mathrm{Ni}_{0.11}$ alloy nanowires. 


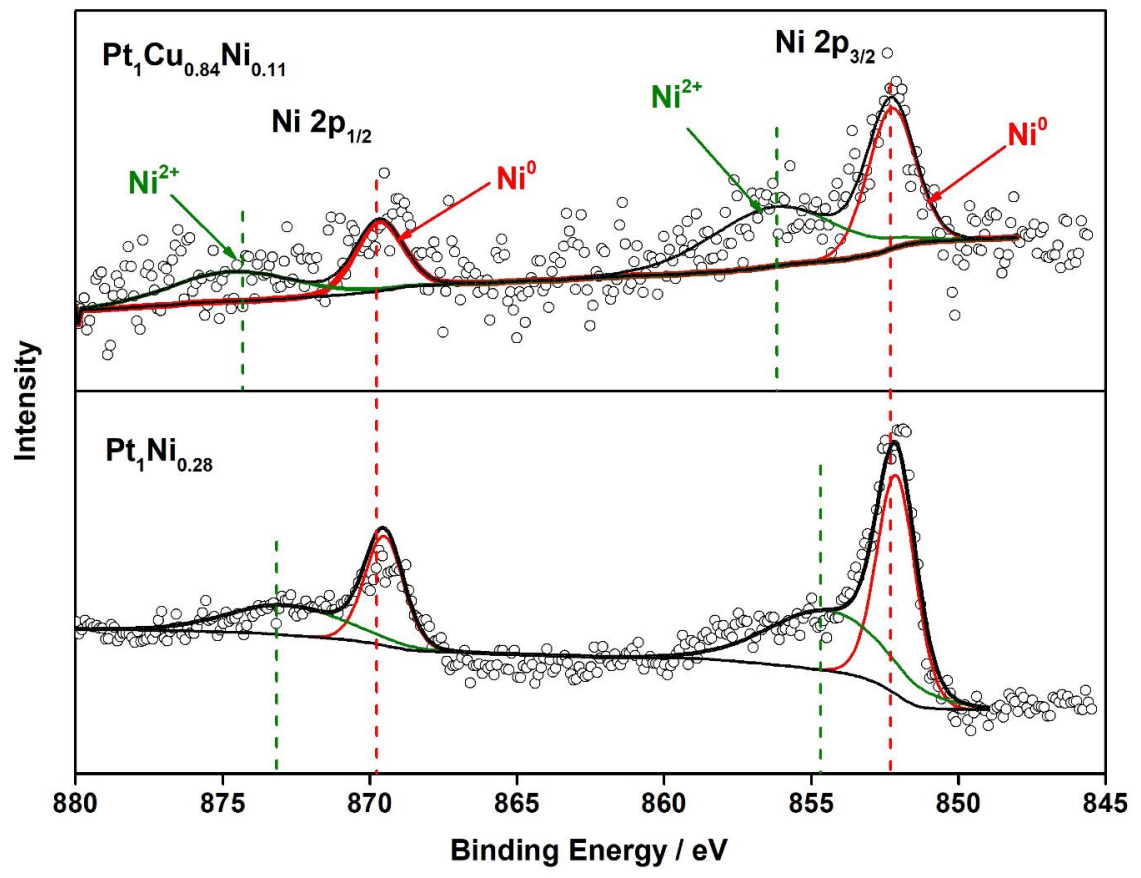

Figure S19. Ni $2 p$ XPS spectra of the $\mathrm{Pt}_{1} \mathrm{Ni}_{0.28}$ and the $\mathrm{Pt}_{1} \mathrm{Cu}_{0.84} \mathrm{Ni}_{0.11}$ alloy nanowires. 
Table S10. Percentages of the $\mathrm{M}^{0}$ and $\mathrm{M}^{2+}$ species in the Pt-Cu-Ni, Pt-Cu, and Pt-Ni alloy nanowires, determined by the area ratios of the XPS peaks.

\begin{tabular}{c|c|c|c|c|c|c}
\hline & \multicolumn{2}{|c|}{$\mathrm{Pt}$} & \multicolumn{2}{c|}{$\mathrm{Cu}$} & \multicolumn{2}{c}{$\mathrm{Ni}$} \\
\hline & 0 & $2+$ & 0 & $2+$ & 0 & $2+$ \\
\hline $\mathrm{Pt}_{1} \mathrm{Cu}_{0.84} \mathrm{Ni}_{0.11}$ & $54.1 \%$ & $45.9 \%$ & $50.4 \%$ & $49.6 \%$ & $52.7 \%$ & $47.3 \%$ \\
\hline $\mathrm{Pt}_{1} \mathrm{Cu}_{0.83}$ & $42.4 \%$ & $57.6 \%$ & $60.9 \%$ & $39.1 \%$ & & \\
\hline $\mathrm{Pt}_{1} \mathrm{Ni}_{0.28}$ & $50.8 \%$ & $49.2 \%$ & & & $54.3 \%$ & $45.7 \%$ \\
\hline
\end{tabular}


Table S11. Bader charge analysis of the Pt-Cu, Pt-Ni, and Pt-Cu-Ni alloy system (unit: $e$ ).

\begin{tabular}{|c|c|c|c|c|c|}
\hline \multicolumn{2}{|l|}{ Entry } & Element & N-charge & A-charge & $\Delta$ charge \\
\hline \multirow{2}{*}{\multicolumn{2}{|c|}{$\mathrm{PtCu}$}} & $\mathrm{Pt}$ & 16 & 16.267 & 0.267 \\
\hline & & $\mathrm{Cu}$ & 11 & 10.663 & -0.337 \\
\hline \multirow{2}{*}{\multicolumn{2}{|c|}{$\mathrm{PtNi}$}} & $\mathrm{Pt}$ & 16 & 16.092 & 0.092 \\
\hline & & $\mathrm{Ni}$ & 10 & 9.612 & -0.388 \\
\hline \multirow{12}{*}{$\mathrm{PtCuNi}$} & \multirow{3}{*}{$1^{\text {st }}$ layer } & $\mathrm{Pt}$ & 16 & 16.294 & 0.294 \\
\hline & & $\mathrm{Cu}$ & 11 & 10.694 & -0.306 \\
\hline & & $\mathrm{Ni}$ & 10 & 9.650 & -0.350 \\
\hline & \multirow{3}{*}{$2^{\text {nd }}$ layer } & $\mathrm{Pt}$ & 16 & 16.286 & 0.286 \\
\hline & & $\mathrm{Cu}$ & 11 & 10.592 & -0.408 \\
\hline & & $\mathrm{Ni}$ & 10 & 9.594 & -0.406 \\
\hline & \multirow{3}{*}{$3^{\text {rd }}$ layer } & $\mathrm{Pt}$ & 16 & 16.304 & 0.304 \\
\hline & & $\mathrm{Cu}$ & 11 & 10.640 & -0.360 \\
\hline & & $\mathrm{Ni}$ & 10 & & \\
\hline & \multirow{3}{*}{$4^{\text {th }}$ layer } & $\mathrm{Pt}$ & 16 & 16.385 & 0.385 \\
\hline & & $\mathrm{Cu}$ & 11 & 10.807 & -0.193 \\
\hline & & $\mathrm{Ni}$ & 10 & & \\
\hline
\end{tabular}

Note: N-charge: Pt 16, $5 \mathrm{p}^{6} 5 \mathrm{~d}^{9} 6 \mathrm{~s}^{1}$; Cu 11, 3d $\mathrm{d}^{10} 4 \mathrm{~s}^{1}$; Ni 10, $3 \mathrm{~d}^{8} 4 \mathrm{~s}^{2}$

A-charge: After optimized, the average value of the outermost charges.

$\Delta$ charge: $\Delta$ charge $=\mathrm{N}$-charge $-\mathrm{A}$-charge 


\section{References}

1. Kresse, G.; Furthmüller, J. Efficient Iterative Schemes for Ab Initio Total-Energy Calculations Using a Plane-Wave Basis Set. Phys. Rev. B Condens. Matter. 1996, 54, 11169-11186.

2. Kresse, G.; Furthmüller, J. Efficiency of Ab-Initio Total Energy Calculations for Metals and Semiconductors Using a Plane-Wave Basis Set. Comput. Mater. Sci. 1996, 6, 15-50.

3. Kresse, G.; Hafner, J. Ab Initio Molecular Dynamics for Liquid Metals. Phys. Rev. B Condens. Matter. 1993, 47, 558-561.

4. Perdew, J. P.; Burke, K.; Ernzerhof, M. Generalized Gradient Approximation Made Simple. Phys. Rev. Lett. 1996, 77, 3865-3868.

5. Grimme, S.; Antony, J.; Ehrlich, S.; Krieg, H. A Consistent and Accurate Ab Initio Parametrization of Density Functional Dispersion Correction (DFT-D) for the 94 Elements H-Pu. J. Chem. Phys. 2010, 132, 154104.

6. Kresse, G.; Joubert, D. From Ultrasoft Pseudopotentials to the Projector Augmented-Wave Method. Phys. Rev. B 1999, 59, 1758.

7. Blöchl, P. E. Projector Augmented-Wave Method. Phys. Rev. B 1994, 50, 17953-17979.

8. Chen, L.; Liang, X.; Li, X.; Pei, J.; Lin, H.; Jia, D.; Chen, W.; Wang, D.; Li, Y. Promoting Electrocatalytic Methanol Oxidation of Platinum Nanoparticles by Cerium Modification. Nano Energy 2020, 73, 104784.

9. Luo, X.; Liu, C.; Wang, X.; Shao, Q.; Pi, Y.; Zhu, T.; Li, Y.; Huang, X. Spin Regulation on 2d Pd-Fe-Pt Nanomeshes Promotes Fuel Electrooxidations. Nano Lett. 2020, 20, 1967-1973.

10. Zhang, W.; Yang, Y.; Huang, B.; Lv, F.; Wang, K.; Li, N.; Luo, M.; Chao, Y.; Li, Y.; Sun, Y.; Xu, Z.; Qin, Y.; Yang, W.; Zhou, J.; Du, Y.; Su, D.; Guo, S. Ultrathin PtNiM (M = Rh, Os, and Ir) Nanowires as Efficient Fuel Oxidation Electrocatalytic Materials. Adv. Mater. 2019, 31, e1805833. 11. Zhang, J.; Li, H.; Ye, J.; Cao, Z.; Chen, J.; Kuang, Q.; Zheng, J.; Xie, Z. Sierpinski GasketLike Pt-Ag Octahedral Alloy Nanocrystals with Enhanced Electrocatalytic Activity and Stability. Nano Energy 2019, 61, 397-403.

12. Wang, Q.; Chen, S.; Li, P.; Ibraheem, S.; Li, J.; Deng, J.; Wei, Z. Surface Ru Enriched Structurally Ordered Intermetallic PtFe@PtRuFe Core-Shell Nanostructure Boosts Methanol Oxidation Reaction Catalysis. Appl. Catal., B 2019, 252, 120-127.

13. Li, J.; Jilani, S. Z.; Lin, H.; Liu, X.; Wei, K.; Jia, Y.; Zhang, P.; Chi, M.; Tong, Y. J.; Xi, Z.; Sun, S. Ternary CoPtAu Nanoparticles as a General Catalyst for Highly Efficient Electro-Oxidation of Liquid Fuels. Angew. Chem. Int. Ed. 2019, 58, 11527-11533.

14. Liu, H.; Liu, K.; Zhong, P.; Qi, J.; Bian, J.; Fan, Q.; Ren, K.; Zheng, H.; Han, L.; Yin, Y.; Gao, C. Ultrathin Pt-Ag Alloy Nanotubes with Regular Nanopores for Enhanced Electrocatalytic Activity. Chem. Mater. 2018, 30, 7744-7751.

15. Yang, P.; Yuan, X.; Hu, H.; Liu, Y.; Zheng, H.; Yang, D.; Chen, L.; Cao, M.; Xu, Y.; Min, Y.; Li, Y.; Zhang, Q. Solvothermal Synthesis of Alloyed PtNi Colloidal Nanocrystal Clusters (CNCs) with Enhanced Catalytic Activity for Methanol Oxidation. Adv. Funct. Mater. 2018, 28, 1704774. 16. Pei, J.; Mao, J.; Liang, X.; Zhuang, Z.; Chen, C.; Peng, Q.; Wang, D.; Li, Y. Ultrathin Pt-Zn Nanowires: High-Performance Catalysts for Electrooxidation of Methanol and Formic Acid. ACS Sustainable Chem. Eng. 2018, 6, 77-81. 
17. Feng, Q.; Zhao, S.; He, D.; Tian, S.; Gu, L.; Wen, X.; Chen, C.; Peng, Q.; Wang, D.; Li, Y. Strain Engineering to Enhance the Electrooxidation Performance of Atomic-Layer Pt on Intermetallic $\mathrm{Pt}_{3} \mathrm{Ga}$. J. Am. Chem. Soc. 2018, 140, 2773-2776.

18. Qin, Y.; Luo, M.; Sun, Y.; Li, C.; Huang, B.; Yang, Y.; Li, Y.; Wang, L.; Guo, S. Intermetallic $h c p-\mathrm{PtBi} / f c c-\mathrm{Pt}$ Core/Shell Nanoplates Enable Efficient Bifunctional Oxygen Reduction and Methanol Oxidation Electrocatalysis. ACS Catal. 2018, 8, 5581-5590.

19. Huang, L.; Zhang, X.; Wang, Q.; Han, Y.; Fang, Y.; Dong, S. Shape-Control of Pt-Ru Nanocrystals: Tuning Surface Structure for Enhanced Electrocatalytic Methanol Oxidation. J. Am. Chem. Soc. 2018, 140, 1142-1147.

20. Zhao, W.-Y.; Ni, B.; Yuan, Q.; He, P.-L.; Gong, Y.; Gu, L.; Wang, X. Highly Active and Durable $\mathrm{Pt}_{72} \mathrm{Ru}_{28}$ porous Nanoalloy Assembled with Sub-4.0 nm Particles for Methanol Oxidation. Adv. Energy Mater. 2017, 7, 1601593.

21. Li, H.-H.; Fu, Q.-Q.; Xu, L.; Ma, S.-Y.; Zheng, Y.-R.; Liu, X.-J.; Yu, S.-H. Highly Crystalline $\mathrm{PtCu}$ Nanotubes with Three Dimensional Molecular Accessible and Restructured Surface for Efficient Catalysis. Energy Environ. Sci. 2017, 10, 1751-1756.

22. Ma, S. Y.; Li, H. H.; Hu, B. C.; Cheng, X.; Fu, Q. Q.; Yu, S. H. Synthesis of Low Pt-Based Quaternary PtPdRuTe Nanotubes with Optimized Incorporation of $\mathrm{Pd}$ for Enhanced Electrocatalytic Activity. J. Am. Chem. Soc. 2017, 139, 5890-5895.

23. Luo, S.; Shen, P. K. Concave Platinum-Copper Octopod Nanoframes Bounded with Multiple High-Index Facets for Efficient Electrooxidation Catalysis. ACS Nano 2017, 11, 11946-11953.

24. Qi, Z.; Xiao, C.; Liu, C.; Goh, T. W.; Zhou, L.; Maligal-Ganesh, R.; Pei, Y.; Li, X.; Curtiss, L. A.; Huang, W. Sub-4 nm PtZn Intermetallic Nanoparticles for Enhanced Mass and Specific Activities in Catalytic Electrooxidation Reaction. J. Am. Chem. Soc. 2017, 139, 4762-4768.

25. Huang, L.; Zhang, X.; Han, Y.; Wang, Q.; Fang, Y.; Dong, S. High-Index Facets Bounded Platinum-Lead Concave Nanocubes with Enhanced Electrocatalytic Properties. Chem. Mater. 2017, 29, 4557-4562.

26. Bu, L.; Feng, Y.; Yao, J.; Guo, S.; Guo, J.; Huang, X. Facet and Dimensionality Control of Pt Nanostructures for Efficient Oxygen Reduction and Methanol Oxidation Electrocatalysts. Nano Res. 2016, 9, 2811-2821.

27. Zhang, N.; Bu, L.; Guo, S.; Guo, J.; Huang, X. Screw Thread-Like Platinum-Copper Nanowires Bounded with High-Index Facets for Efficient Electrocatalysis. Nano Lett. 2016, 16, 5037-5043.

28. Hunt, S. T.; Milina, M.; Alba-Rubio, A. C.; Hendon, C. H.; Dumesic, J. A.; Román-Leshkov, Y. Self-Assembly of Noble Metal Monolayers on Transition Metal Carbide Nanoparticle Catalysts. Science 2016, 352, 974.

29. Bu, L.; Guo, S.; Zhang, X.; Shen, X.; Su, D.; Lu, G.; Zhu, X.; Yao, J.; Guo, J.; Huang, X. Surface Engineering of Hierarchical Platinum-Cobalt Nanowires for Efficient Electrocatalysis. Nat. Commun. 2016, 7, 11850.

30. Bu, L.; Zhang, N.; Guo, S.; Zhang, X.; Li, J.; Yao, J.; Wu, T.; Lu, G.; Ma, J.-Y.; Su, D.; Huang, $\mathrm{X}$. Biaxially Strained $\mathrm{PtPb} / \mathrm{Pt}$ Core/Shell Nanoplate Boosts Oxygen Reduction Catalysis. Science 2016, 354, 1410-1414. 
31. Ding, J.; Bu, L.; Guo, S.; Zhao, Z.; Zhu, E.; Huang, Y.; Huang, X. Morphology and Phase Controlled Construction of Pt-Ni Nanostructures for Efficient Electrocatalysis. Nano Lett. 2016, 16, 2762-2767. 